التوزيع الجغرانــي لمرتكبــي جريمتي القتل والسرقسة في همافظسـة واســـ (دراسة في جغرافية السكان)

أ. د. لطيف هاشم كزار الطائي / كلية التربية / جامعة واسط

الباهث . وسام عبد المسسز عجيل/ كلية التربية / جامعة واسط



تُعد الجريمة ظلاهرة اجتماعية عانت منها المجتمعات الإنسانية منذ القدم، وعانت على مر السنين نظر اً لمـا تتسبب فيهِ من أخطار و أثار سلبية على الفرد والمجتمع، حيث تعمل على أثنارة الرعب و إثـاعة الخوف و الذعر في

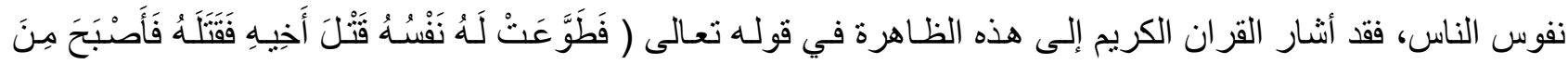

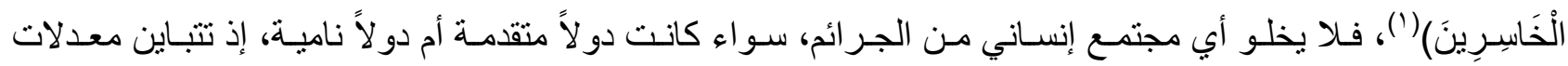
الجريمة من مجتمع إلى آخر من حيث نوع وحجم الجريمة، بل وتتباين داخل المجتمع الو احد مهما كانت درجـة نضـوجِه الفكري و الثقافي و السياسي .

فالحضار ات التاريخية القديمة كالحضارة الصينية واليابانية كان الاعتقاد السـائد فيها أن الجريمـة هي من عمل

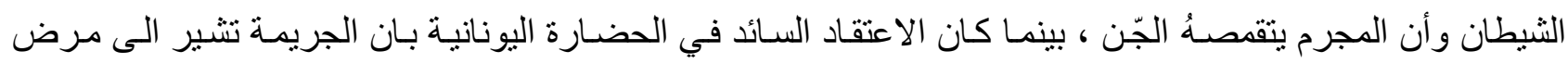
الأنسان النفسي تتسبب فيهِ الانفعالات الداخلية والجهل و البحث عن الثههوة و اللذة (؟). ما بالنسبة لحضـارة و ادي الر افدين

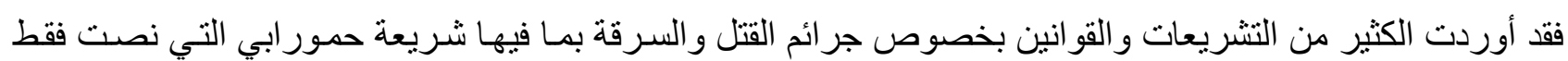

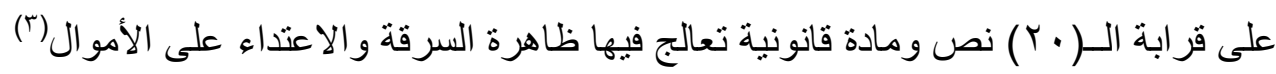
تشكل الظروف الاجتماعيـة الصـبة التـي يعيثـهـا المجتمـع العر اقي المتمثلـة بارتفـاع معدلات الفقر والبطالـة

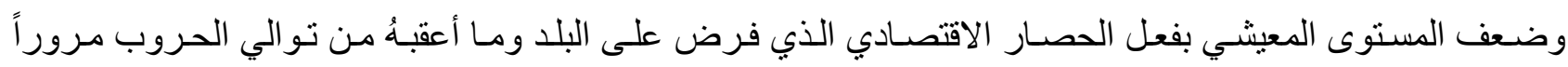
بـالاحتلال الأمريكي بعد عـام (r . . r م) و السى وقتنـا الحسالي جملـة مـن المتغيرات أدت الى انهيـار تـام في العديد من المؤسسـات الأمنيـة والخدميـة وتزايـ حجم المظـاهر الإجر اميـة وتتوع مظـاهر السلب و النهب و القتل والاستنيلاء على

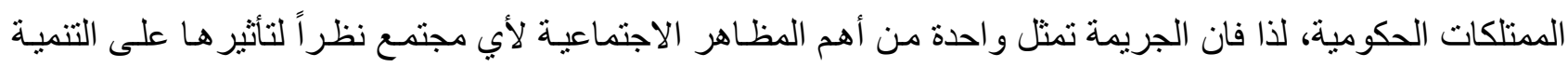
البشرية و البنـاء الاجتمـاعي وضـف تماسكك المجتمع فضـلا عن تأثير هـا على كافة المجالات الاقتصـادية و الاجتماعبـة و الأمنية لأي مجتمع، لذا كان الاهتمام منصباً من قبل الدر اسات الجغر افية وبصفة خاصة در اسات الجغر افية الاجتماعيـة من اجل الوصول إلى الحلول و المعالجات المناسبة للحد من هذهِ الظاهرة والقضاء عليها بكافة إثكالها . 
أن مشكلة البحث تتمثل بمجموعة من التساؤلات التي تحاول الدراسة الإجابة عنها بالنقاط التالية:ا - هـل يتبـاين التوزيع الجغر افي لمرتكبـي جريمتي القتل و السـرقة زمانيـاً ومكانيـاً مـابين الوحدات الإداريـة في منطقة الدر اسةة .

r- هل هناك تباين في التوزيع الجغر افي لمرتكبي ومرتكبات جريمتي القتل و السرقة في منطقة الدراسة .

\section{Importance of The study}

أهمية البحث:تتضح أهمية البحث في الكثف عن التباين المكاني لمرتكبي جريمني القتل والسرقة في محافظة واسط وأرتفاع معدلات وانمـاط الجريمـة جر اء تردي و غيـاب الأمـن و الاستقر ار(غياب سلطة القـانون) ممـا ادى الـى تتـوع المظـاهر الاجر امية والسلوك الانحر افي في المجتمع العراقي .

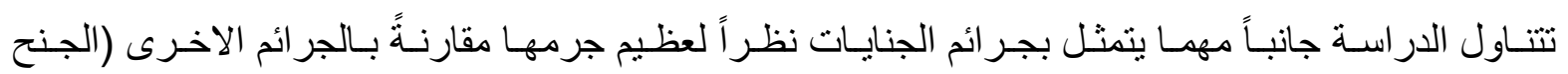
و المخالفات) والتي تكون أقل جسامه في أحكامها، لذا فأن البحث يشير الى خطورة وقع الجريمـة على الفرد والمجتهع حيث تشكل جريمـة القتل التهديد الرئيس لحياة الانسـان ومـا يترتب عليها من أضـرار وخسائر بشرية وماديـة جسيمة تتمثنل بـالأرواح و الممتلكات و أثارت الفوضسى وانعدام الأمن، في حين تمثنل جريمـة السرقة واحدة من أكثر الجرائم انتشار اً في العالم والتي تحدث نتيجةً لانخفاض المستوى المعيثـي وارتفاع نسبة الفقر و البطالـة. وجاءت اهمية البحث لكونه يعد الدراسة الأولى من نوعها في الادبيات الجغر افيـة التي تكثف عن التباين المكاني لمرتكبي جريمتي القتل

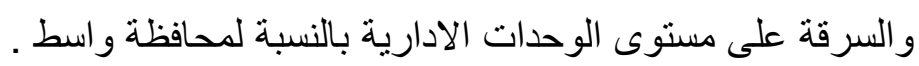

The Limits of The study حدود منطقة البحث :-

تتألف حدود منطقة البحث من الحدود المكانية والحدود الزمانية فمكانياً يلاحظ من الخريطة ( (1) أن محافظة و اسـ تقع في الجزء الجنوبي الثـرقي من المنطقة الوسطى للســل الرسـوبي مـن العر اق مـابين دائرتـي عرض (-

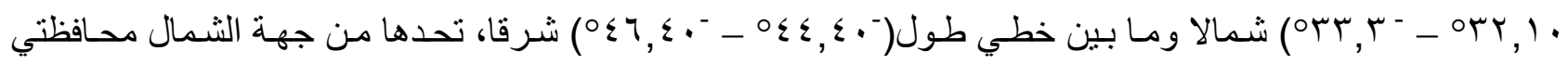
بغداد وديالى ومن الجنوب و الجنوب الثرقي محافظــتي ذي قار وميســــان ومن الثـــرق جمهوريـة إيران الإسـلامية

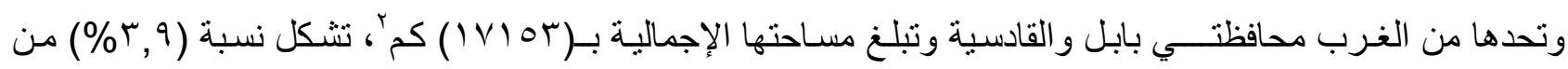

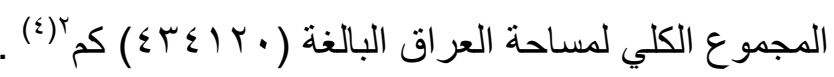


خريطة ( ) موقع محافظة واسط من العراق

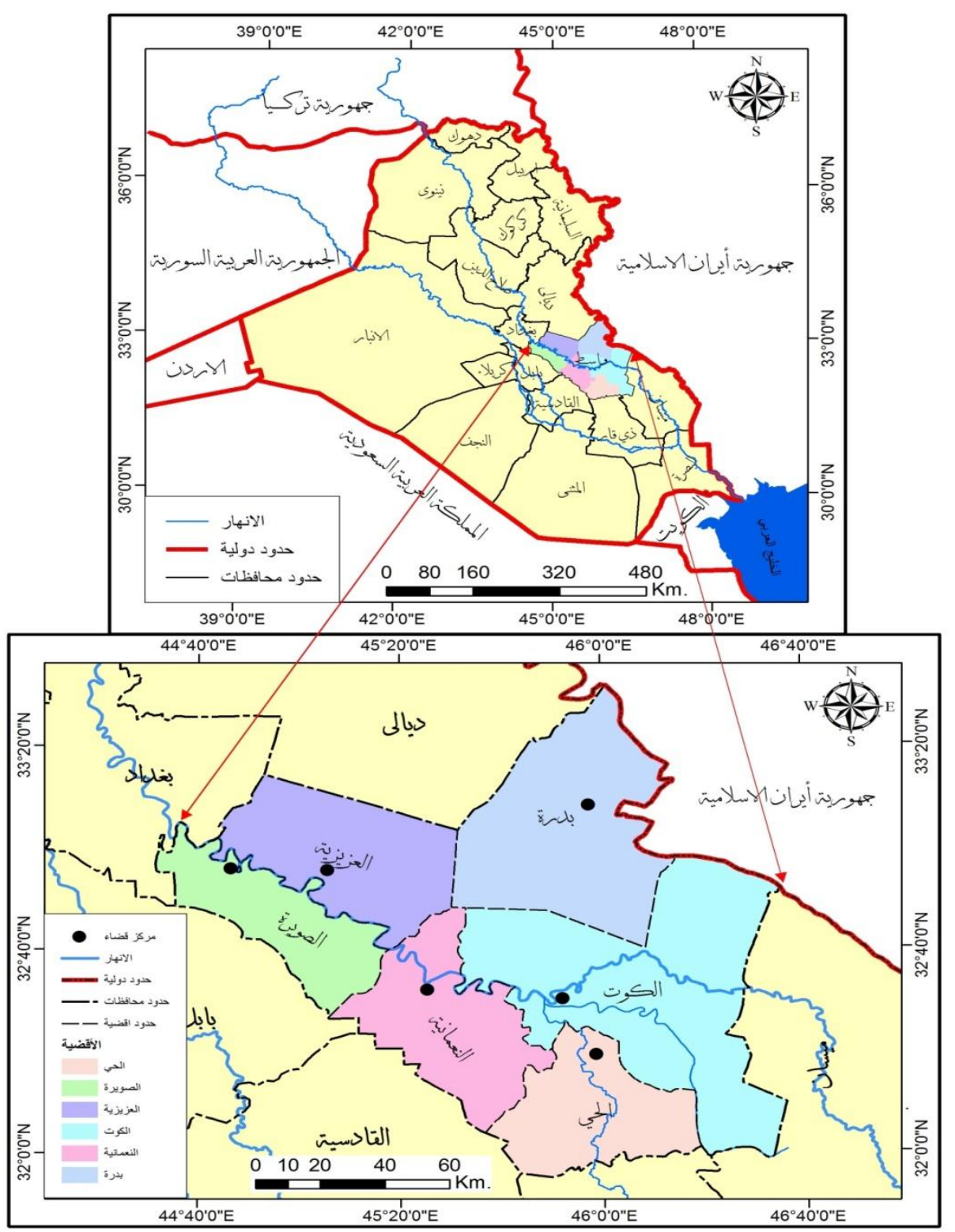

المصدر : الباحث بالاعتماد على الهيأة العامة للمساحة، خريطة العر اق الادارية، بغداد، ب ا ب.

تتمثل منطقة الدراسة بعدد من الوحدات الادارية تبلغ (IV ) وحدة إدارية منها (T) مر اكز أقضية و(I (I) وحدة ناحية ادارية أذ تم اعتمـاد الناحية بوصفها اصغر وحدة إداريـة يمكن الحصول على بياناتها لمعالجـة مشكلة الدر اسـة، ولتساعد على كثف صورة التوزيع المكاني لمرتكبي جريمتي القتل و السرقة في عموم منطقة الدراسة ـ وكما يلاحظ أما بالنسبة لحدود الدر اسة الزمانية، فان تلك الحدود تمثلت بالبيانـات الجنائيـة الخاصـة بمرتكبي جريمتي القتل

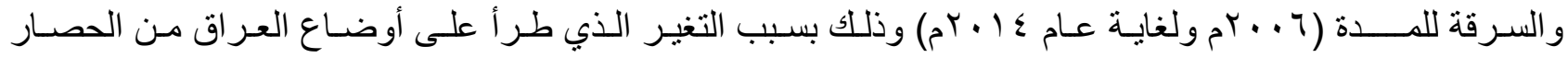

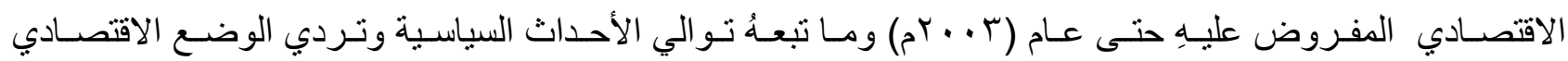

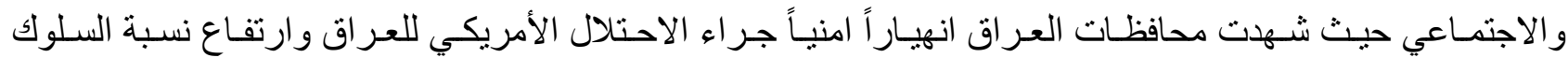
الإجر امي و المظاهر الانحر افية. 


$$
\text { خريطة (؟) محافظة واسط حسب الوحدات الادارية }
$$

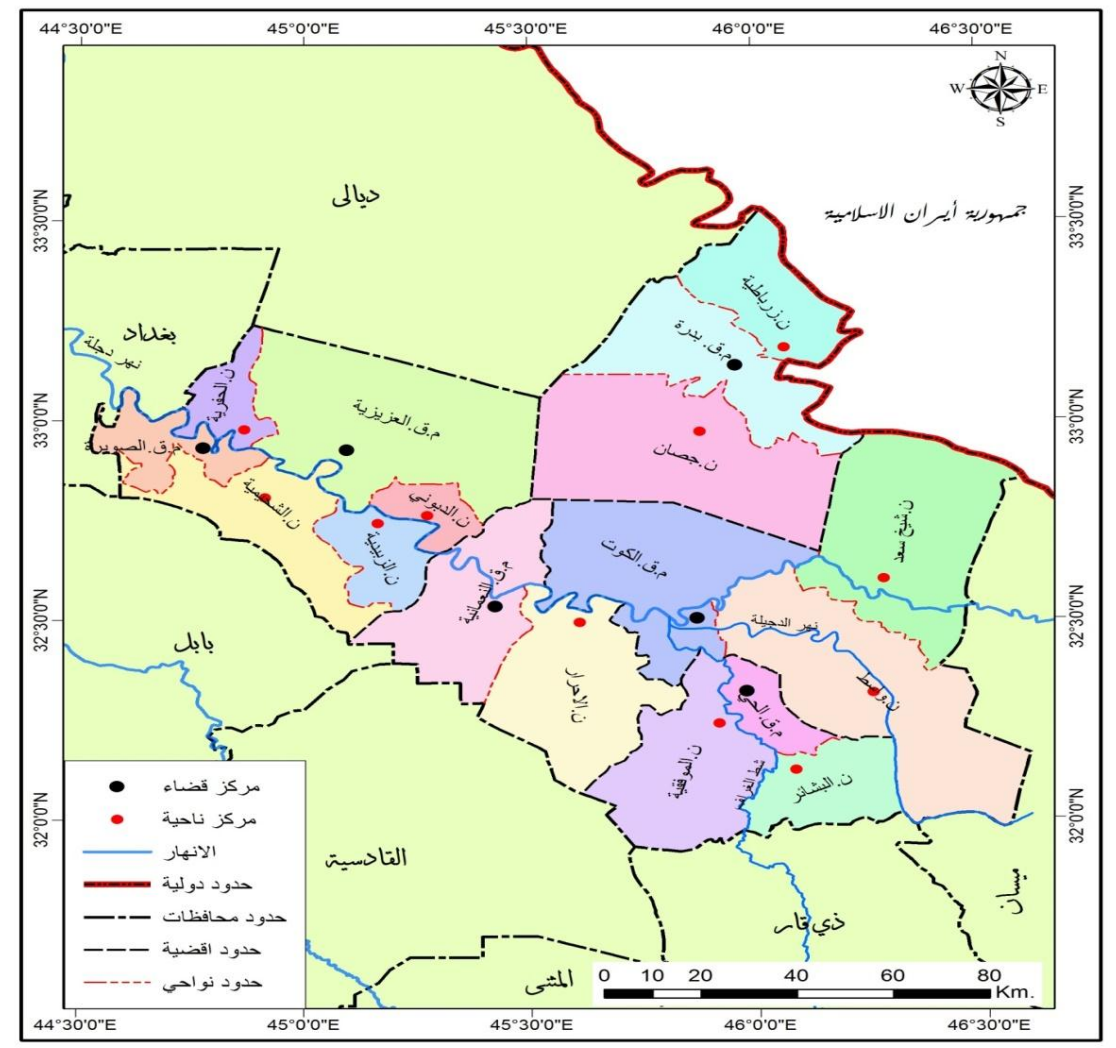

المصدر: الباحث بالاعتماد على الهيأة العامة للمساحة، خريطة محافظة واسط، بغداد، ب ا ـ ب .

اعتمدت الدراسة على المنهج الوصفي التحليلي لمعرفة مستوى التباين المكاني لمرتكبي جريمتي القتل

و السرقة ومدى خطورتها و أثنار ها على المجتمع وتحليل اسباب تباينها واعتماد المنهج المسحي في جمع البيانات القائمـة على الملاحظـة واجر اء المقابلات الثخصية بالإضـافة الى استخدام الأسـاليب الاحصـائية (الكميـة) في تحليل ظـاهرة الجريمـة المتمثلة بمقياس التنتتت والتركز( كالدرجـة المعياريـة و الوسط الحسـي) واستخر اج النتائج ووضـع الجداول

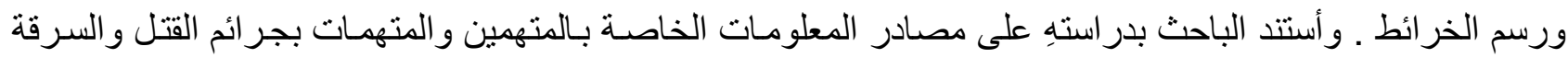



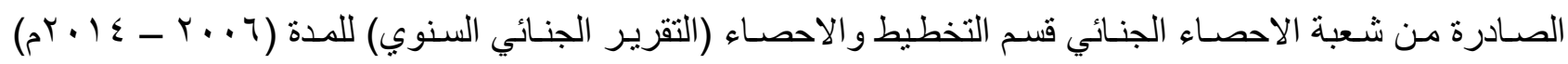
و المحاكم التابعة لمنطقة الدر اسة وشعبة مكافحة إجر ام و اسط، وبالاعتماد على الدر اسة المكتبية ذات العلاقة بالموضوع من المر اجع والكتب العلمية والمجلات و الإصدارات الرسمية. واستكمالا لما تقدم ومن أجل التوصل إلى نتائج واضحة فان الدر اسة تناولت التوزيع العددي و المرتبي لمرتكبي جر ائم القتل والسرقة في محافظة واسط ومن ثم الاستتناجات و المقترحات وقائمة بأسماء المر اجع و المصادر. 
The terms and concepts of The study هصطحات وهفاهبيم البحث:-

تشتمل الدر اسة على العديد من المفاهيم والمصطلحات الخاصة بالتباين المكاني لمرتكبي جريمتي القتل

و السرقة والتي سعت الدر اسة الى توضيحها فقد وردت عدة تعـاريف تخص الجريمـة وردَ ذكرهـا في مختلف الثـر ائع و القو انين بحسب وجهات النظر الخاصـة بكل تعريف، فتم تعريف الجريمـة من الناحية الاجتماعيـة والناحيـة القانونية و النفسية و السياسية مما يدل على تعقيد هذِِ الظـاهرة وتداخلها بمختلف نو احي الحياة، و هنـا لابد من استعر اض لبعض من أهم المفاهيم الخاصة بموضوع البحث و على النحو الاتي :-

\section{The General Definition of The Grime}

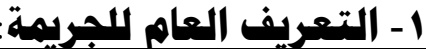

وتعرف الجريمة أيضا بأنها ظاهرة اجتماعية ونوع من السلوك الثـاذ لا يخلو منـهُ اي مجتمع من المجتمعات

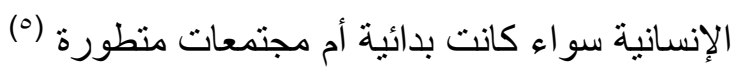

The Language of The Grime

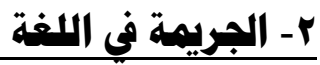



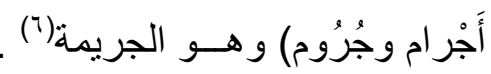

The Murder in Language

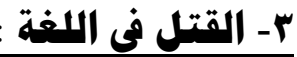

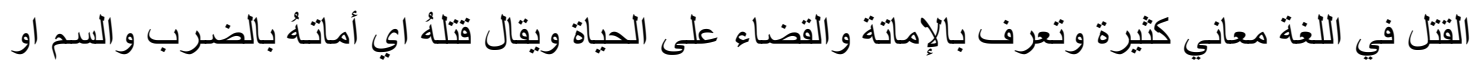

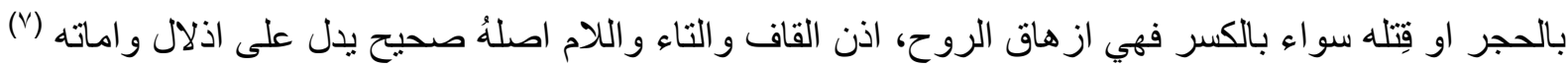

The Robbery in Language

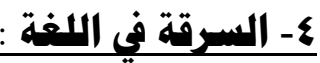

السرقة لغويـاً وهي أخذ المسال على جهة الاختفاء، فالسرقة هنا تنم قراءتها بكسر الراء(^)،أما بالنسبة

للمشرع العر اقي فقد عَرفة السرقة بأنها اختلاس المال منقو لاً مملوك لغير الجاني عمداً من دون أر ادة المجني عليه(9).

The Grime Geography

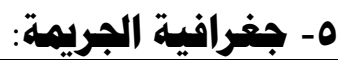

وهي در اسة الأبعاد المكانيـة للجريمـة في الحيز الجغر افي، متمثلتاً بدر اسـة لأهمالسمات و الخصـائص المكانيـة

للجريمة وتأثثر اتها الاجتماعية والاقتصادية والسياسية والأمنية، فالجريمـة هنـا وجـه من أوجـه العلاقـة المكانيـة مـا بين الأفر اد وبيئاتهم(·) ـ وتعد جغر افية الجريمة من المو اضيع الفرعية في علم الجغر افيـة تدرس التنظيم المكاني لظـاهرة الجريمة فهي تفسر وتربط الحيز الجغر افي للمجرمين ومختلف الأفعال الاجر امية بالإضـافة الى دراسـة التباين المكاني للجريمة ومعدلاتها وخصائص مرتكبي الجريمة والعو امل المؤثرة فيهاب(') .

\section{التوزيع الجغرافي لمرتكبي جريمتي القتل والسرقة في هحافظة واسط}

ان دراسة التوزيع الجغر افي (*) لأي ظاهرة سكانية تعد من الموضو عات المهـة التي تعالجها جغر افيـة السكان سو اء كان ذلك من وجهة نظر الاهتمام العام والاهمية النظرية أو من وجهة الفائدة أو التطبيق، وبذلك فأن دراسـة توزيع 
الظـاهرة السـكانية تُعـد مـن أهـم الظـواهر الجغر افيـة التـي تهـتم بهـا جغر افيـة السـكان، حيـث يمثل التوزيـع المكـاني و الاختلافات المكانية لخصائص السكان الخطوط المشتركة في جغر افيـة السكان التي تهدف الى تعريف وبيـان اهميـة الاختلافات بين مكان وأخر في عدد السكان ونوعهم ـ وبناءاً على ذللك فأن دراسـة التوزيع الجغر افي لمرتكبي جريمتي القتل و السرقة تُعد من المو اضيع المهمة و الأساسية التي تحظى بأهمية خاصة في الدر اسـات الجغر افية السكانية، لكونها

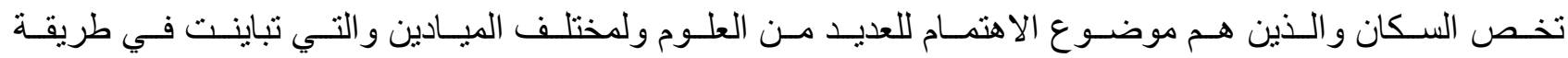
در استها للكثير من القضايا الخاصة بالسكان و التي تحاول الجغر افية الإجابة عنها ـ و عليهِ فأن در اسـة التوزيع الجغر افي لمرتكبي جر ائم القتل و السرقة حسب الوحدات الإداريـة تُعد من الأساسيات المهمـة وذلك لغرض الكثف عن مدى التباين المكاني لمرتكبي الجر ائم في عموم محافظة واسط .

\section{التوزيـع العـددي والمرتبي لمرتكبـي وهرتكبات جرائسم القتسل والسرقسة في هحافظة واسط}

يقصد بالتوزيع العددي(*)(The Numerical Distribution) لمرتكبي الجرائم توزيعهم بالأرقام المطلقة للوحدات الإدارية في المحافظة إذ يكثف هذا التوزيع عن التباين المكاني لحجم المجرمين ضمن المنـاطق والوحدات الإدارية المختلفة والذي يتم حصرهُ من قبل الجهات ذات العلاقة المتمثلة بمجلس القضاء الأعلى لرئاسـة استئناف و اسط


العددي و المرتبي من الوسائل التي يمكن تمثيلها على الخريطة بالاعتماد على مدى تو افر البيانات الرقمية الخاصـة بكل وحدة إدارية حيث توضح هذهِ البيانات نسب الاختلاف بحجم الظاهرة المطلوب در استها زمانياً ومكانياً. يتضح من الجدول( ( ) والثكل( (1) أعداد مرتكبي جريمتي القتل والسرقة والتي شـهدت تذبذباً واضحساً

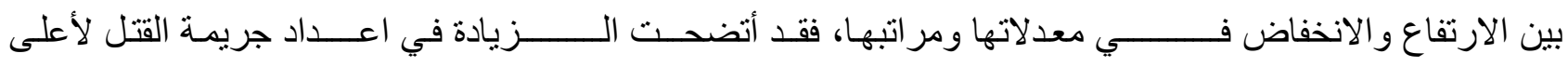

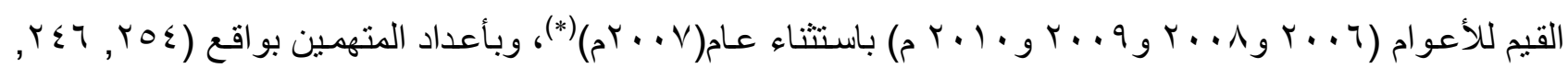

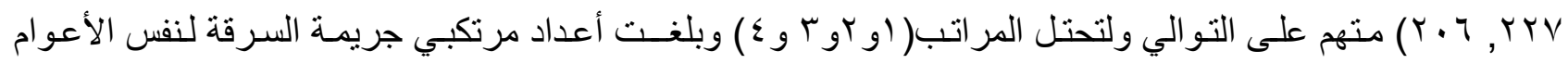

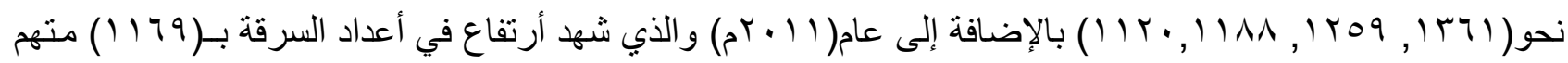



و • 1 • م م) و هي بذلك تشكل أعلى معدلات جريمني القتل والسرقة التي شهدتها محافظة واسط لسنوات الدراسة.

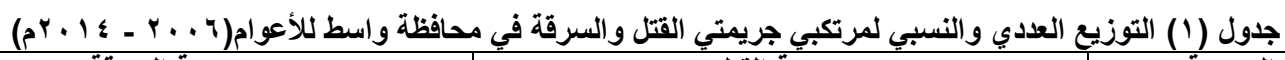

\begin{tabular}{|c|c|c|c|c|c|c|}
\hline \multicolumn{3}{|c|}{ جريمة السرقة } & \multicolumn{3}{|c|}{ جريمة القتل } & \multirow{2}{*}{ نوع الجريمة } \\
\hline$\%$ & المرتبة & العدد & $\%$ & المرتبة & العدد & \\
\hline 17,8 & 1 & 1471 & 10,8 & 1 & YOS & $r \ldots q$ \\
\hline - & - & - & - & - & - & $\left.{ }^{*}\right)^{4} \cdot . \mathrm{V}$ \\
\hline 10,1 & $r$ & $1 r 09$ & 10 & $r$ & $r \leq 7$ & $r \ldots \Lambda$ \\
\hline $1 \leqslant, r$ & $r$ & 1111 & $1 \pi, \Lambda$ & $r$ & YYV & $r \ldots 9$ \\
\hline 14,0 & 0 & $11 \%$ & 14,0 & $\varepsilon$ & $r \cdot q$ & $r+1$. \\
\hline 18 & $\varepsilon$ & 1179 & 11,7 & 0 & 191 & $r .11$ \\
\hline$\wedge, \wedge$ & $\mathrm{V}$ & $V Y \wedge$ & $11, r$ & 7 & $1 \wedge \varepsilon$ & $r+1 Y$ \\
\hline 9,9 & 7 & Aro & $1 \cdot, 0$ & $\mathrm{v}$ & IVY & $r .1 r$ \\
\hline$\Lambda$ & $\Lambda$ & $77 \leq$ & 1. & $\Lambda$ & 178 & $r+1 \leq$ \\
\hline$\%$ & - & ANI & $\%$ & - & $17 \leqslant \leq$ & المجموع \\
\hline
\end{tabular}


المصدر: الباحث بالاعتماد على رئاسة استثناف واسط الاتحادية، قسم التخطيط والإحصاء، بيانات رسمية (غير منشورة) لعام \& 1 ب بم .



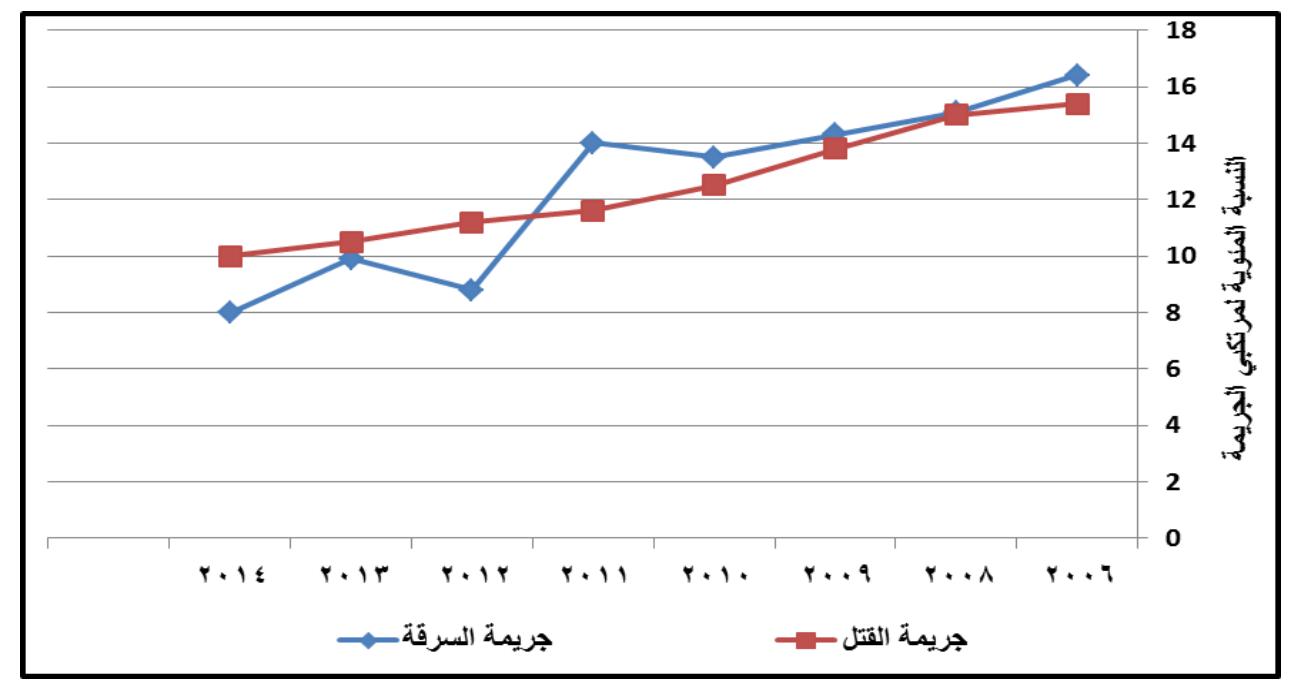

المصدر: الباحث بالاعتماد على جدول( ) -

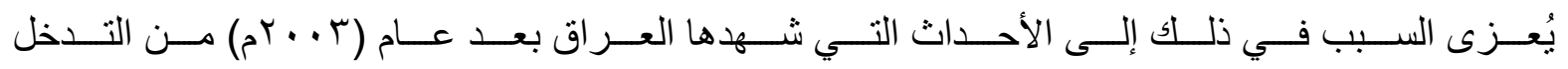
العسكري الأمريكي وتردي الوضع الأمني والاقتصادي على حدٍ سواء وبروز النظام القَبلي العشـائري بصورة واضحة و الذي تميز بأحكامهِ بحسب العادات و التقاليد والأعر اف الاجتماعية السائدة في المجتمع و المتمتلة بقانون الفصل والثأر و النَهْوة و غير ها من الأنظمة القبلية المتعارف عليها دون الرجوع إلى السلطة القضائية في تللك الآونـة، يضـاف إلى ذلك ما كان سائداً في ذلك المجتمع ذو الطابع الريفي من مشـاكل اجتماعية كالخلافـات المتعلقة بحدود الأراضـي الزر اعيـة


بصفة عامة جر اء حالة التهميش و الفقر والبطالة التي ساعدت على الانقلاب الأمني وشيوع ما يسمى بــ(السَّلب و النَهب) لممتلكات الدول من دون أي مبرر أو مسوغ قانوني ممـا أدى بطبيعـة الحسال إلى انتشـار الظواهر الإجراميـة كالعنف

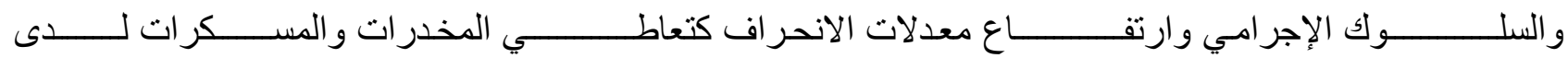
فئة الثباب نتيجة الفراغ الأمني والسياسي و التفكك الأسري الذي أصاب الكثير من العوائل العراقية(rال) شهدت الأعو ام التي تلت عام (• ( • r م) انخفاض في أعداد المتهمين بجرائم القتل والسرقة في عموم منطقة

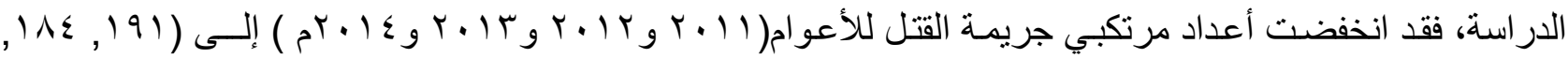

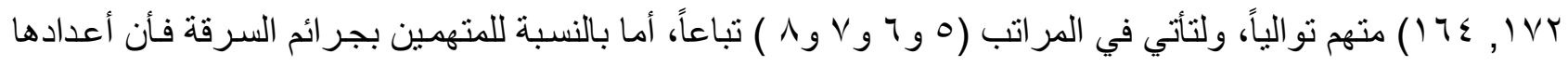

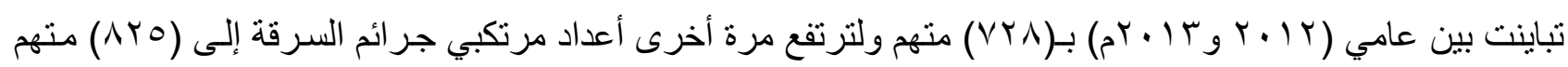
لعام (r ( • rم) ولتحتل المراتب (V و ^) على التو الي، أما بالنسبة لعام (ع ( • rم) فقد سجلت أعداد المتهمين بالسرقات أقل الاعداد لسنوات الدر اسة بواقع (ع 77) جريمة سرقة في المرتبة الأخيرة ـ وعند الحديث عن جرائم النساء آذ يكاد لا يخلو ا أي مجتمع من المجتمعات من جرائم الإنـاث الآ إنها بصفة عامـة أقل مقارنـةً بجر ائم الذكور يكاد يتصف بهذهِ 
الصفة المجتمع العربي و السبب في ذلك يعود إلى عدم معرفة الحجم الحقيقي لمرتكبات الجرائم نظر اً للعُرف الاجتمـاعي السائد في المجتمع، إذ لا يتم الإفصاح عن الكثير من جرائم الإناث وبصفة خاصة جريمة السرقة وذلك لعدم التشهير بها و الأساء لسمعتها وعائلتها إذ يتم تسوية الكثير من هذِِ الجرائم عشائرياً دون اللجوء إلى الجهات المختصـة للتبليغ عنها وبصفة خاصة المناطق الريفية، أو نظر أللقصور في دور الأجهزة الأمنية والاستخبار اتية وعدم وجود الكوادر النسـائية ضمن أجززة الثرطة الخاصة بالكثف عن هذهِ الجرائم .

يثير الجدول(r) و الثكل (r) إلى تباين أعداد مرتكبات جريمتي القتل و السرقة في عموم منطقة الدراسـة، فقد

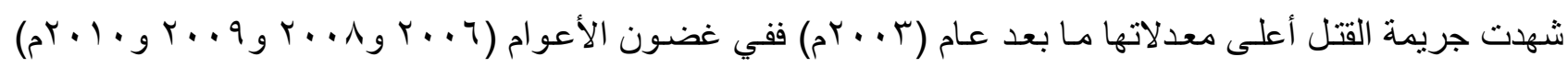

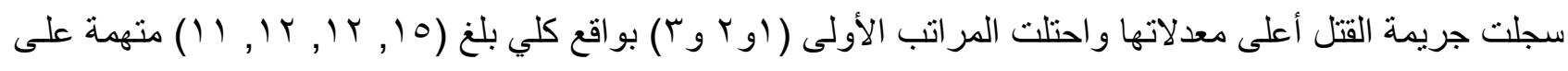

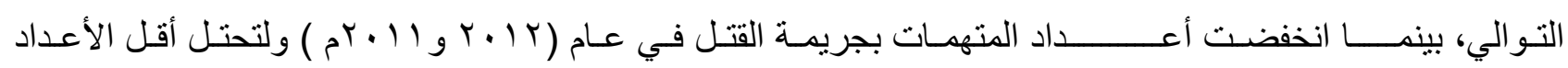
بالنسبة لمرتكبات جريمة القتل بـ ^ و V) متهمات تباعاً، في حين شهدت معدلات جر ائم الإنـاث بعد ذلك ارتفاعاً نسبياً

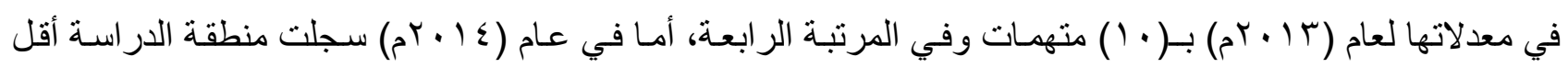
معدلات جر ائم القتل بو اقع (9) منهمات في المرتبة الخامسة والأخيرة .



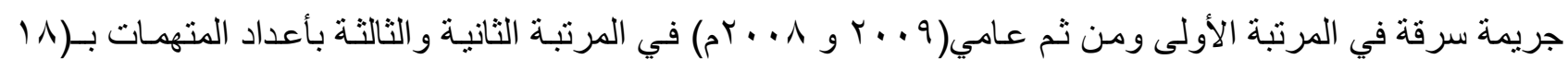



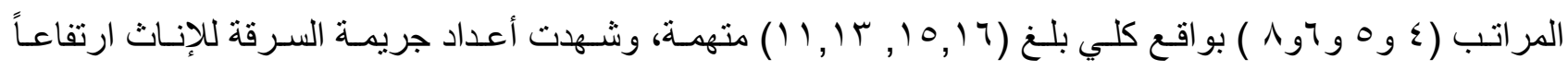
تدريجياً بو اقع (r ( ) متهمة لعام (ع ( • r ) ) في المرتبة السابعة. كما وتباينت أعداد مرتكبي جريمتي القتل والسرقة

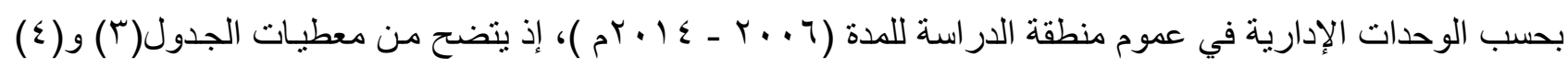
الأتي :- (20 - n

ا ـ جاء مركز قضاء الكوت بالمرتبة الأولى بالنسبة لمرتكبي جريمة القتل طو ال مدة الدراسـة مستحوذاً على النصيب

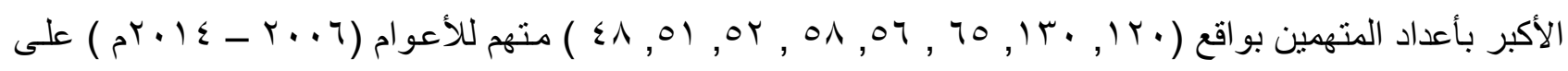
التو الي . n

r- تَسيد مركز قضاء الكوت على المرتبة الأولى بأكبر الأعداد بالنسبة لمرتكبي جريمـة السرقة في عموم منطقة



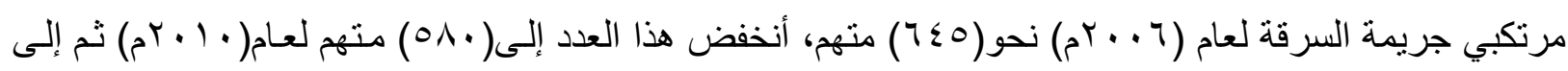

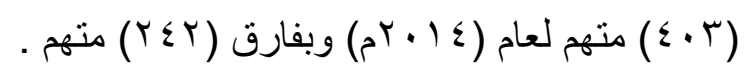

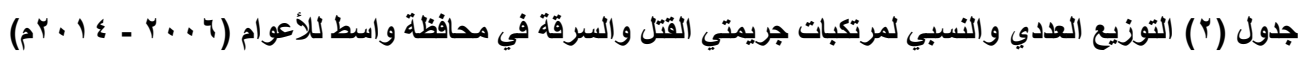

\begin{tabular}{|c|c|c|c|c|c|c|}
\hline \multicolumn{3}{|c|}{ جريمة السرقة } & \multicolumn{3}{|c|}{ جريمة القتل } & نوع الجريمة \\
\hline$\%$ & المرتبة & العدد & $\%$ & المرتبة & العدد & السنوات \\
\hline $1 V, 1$ & 1 & YI & $1 V, 9$ & 1 & 10 & $r \ldots r$ \\
\hline $1 \pi, \Lambda$ & $r$ & IV & $1 \leqslant, r$ & $r$ & Ir & $r \ldots \Lambda$ \\
\hline
\end{tabular}




\begin{tabular}{|c|c|c|c|c|c|c|}
\hline $1 \leq, 7$ & $r$ & 11 & $1 \leqslant, r$ & $r$ & $1 r$ & $r \ldots q$ \\
\hline 14 & $\varepsilon$ & 19 & 14,1 & $r$ & 11 & $r+1$. \\
\hline${ }^{\prime} r, r$ & 0 & 10 & 9,0 & 7 & $\Lambda$ & $r .11$ \\
\hline $1 \cdot, 7$ & 7 & $1 T$ & $\Lambda, r$ & $\mathrm{~V}$ & $\mathrm{~V}$ & $r .1 r$ \\
\hline $1, q$ & $\Lambda$ & 11 & 11,9 & $\varepsilon$ & 1. & $r .1 r$ \\
\hline $9, \wedge$ & $V$ & Ir & $1 \cdot, V$ & 0 & 9 & $r+1 \leq$ \\
\hline$\% 1 \ldots$ & - & IYr & $\% 1 \ldots$ & - & $\Lambda \leq$ & المجموع \\
\hline
\end{tabular}

المصدر: الباحث بالاعتماد على رئاسة استئناف واسط الاتحادية، قسم التخطيط والإحصاء، بيانات رسمية (غير منشورة) لعام \& 1 • بم •

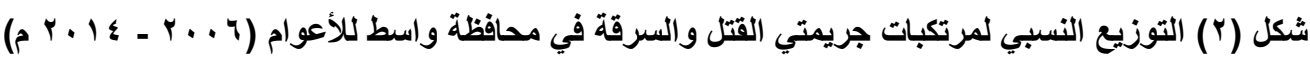



المصدر : الباحث بالاعتماد على جدول(r) -

r- تنافس على المر اتب الثلاثة الأولى بعد مركز قضاء الكوت بأجمالي أعداد مرتكبي جرائم القتل كل من مركز قضـاء

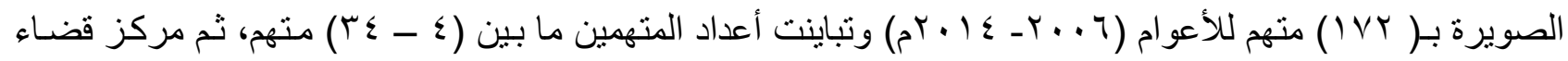



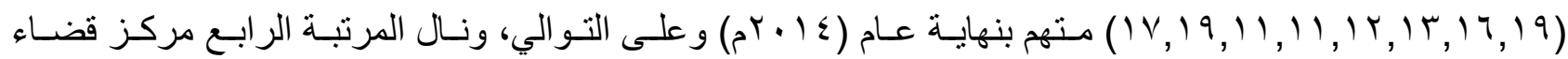

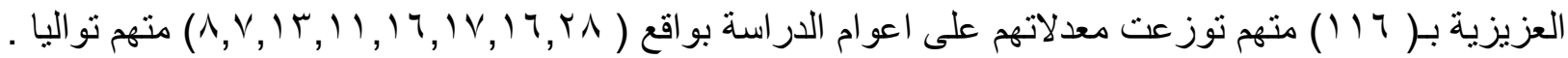

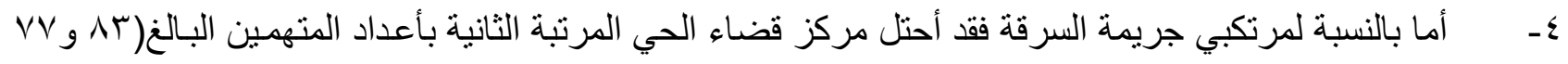

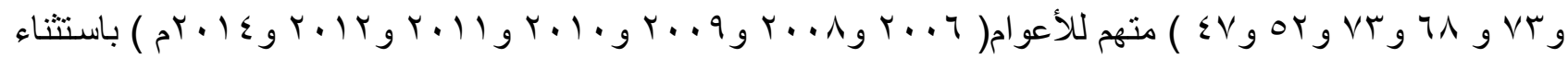
عام (r ( • rم) في المرتبة الثالثة مناصفة مع مركز قضاء الصويرة بـ( ( ) متهم . 




\begin{tabular}{|c|c|c|c|c|c|c|c|c|c|c|c|c|c|c|c|c|c|}
\hline \multirow[t]{2}{*}{ المجموع } & \multicolumn{2}{|c|}{$Y \cdot I \leqslant$} & \multicolumn{2}{|c|}{$r \cdot 1 T$} & \multicolumn{2}{|c|}{$Y \cdot I Y$} & \multicolumn{2}{|c|}{$r .11$} & \multicolumn{2}{|c|}{$r+1}$. & \multicolumn{2}{|c|}{$Y \ldots q$} & \multicolumn{2}{|c|}{$Y \cdots A$} & \multicolumn{2}{|c|}{$r \ldots r$} & \multirow{2}{*}{ الوالدارية } \\
\hline & المرتبة & العدد & المرتبة & العدد & المرتبة & العدد & المرتبة & العدد & المرتبة & العدد & المرتبة & العدد & المرتبة & العدد & المرتبة & العدد & \\
\hline $0 \wedge$. & 1 & $\leqslant \wedge$ & 1 & 01 & 1 & or & 1 & $0 \wedge$ & 1 & 04 & 1 & 90 & 1 & ir. & 1 & Ir. & مركز قضاء \\
\hline$\Lambda \Lambda$ & $\varepsilon$ & 1. & $\varepsilon$ & 14 & $\Lambda$ & $\mathrm{v}$ & 7 & $\Lambda$ & 9 & $\Lambda$ & 9 & 9 & $r$ & 19 & $\varepsilon$ & $1 \varepsilon$ & ناحية شيخ سعد \\
\hline$V \varepsilon$ & $r$ & ir & V & 9 & 1. & 0 & 9 & $\varepsilon$ & V & 1. & $\mathrm{~V}$ & 11 & $\xi$ & $1 \varepsilon$ & V & $\Lambda$ & ناحية واسط \\
\hline 111 & r & IV & r & 19 & $\varepsilon$ & 11 & $\varepsilon$ & 11 & 0 & Ir & 0 & ir & $r$ & 18 & $r$ & 19 & مركز قضاء \\
\hline$V \varepsilon$ & 0 & $\Lambda$ & 7 & 1. & 7 & 9 & 0 & 1. & 7 & 11 & $\Lambda$ & 1. & 0 & 9 & $\Lambda$ & V & ناحية الاحرار \\
\hline $9 \mathrm{~V}$ & $\varepsilon$ & 1. & 0 & 11 & $r$ & ir & $r$ & 17 & $\varepsilon$ & $1 \varepsilon$ & $\varepsilon$ & 10 & 7 & v & 7 & 1. & مركز قضاء \\
\hline$\leqslant 9$ & 7 & $\mathrm{v}$ & $\Lambda$ & $\Lambda$ & $\Lambda$ & $\mathrm{v}$ & $\Lambda$ & 7 & 1. & $\mathrm{~V}$ & 1. & $\Lambda$ & 1. & $\mu$ & IT & $r$ & ناحيةٌ البشائر \\
\hline rq & $\Lambda$ & 0 & 1. & 7 & 9 & 7 & V & V & 11 & 0 & Ir & 7 & 11 & r & $1 \pi$ & $r$ & ناحية الموفقية \\
\hline$ץ \varepsilon$ & 1. & $r$ & Ir & $\varepsilon$ & ir & $r$ & 11 & r & ir & r & ir & $r$ & 11 & r & 1. & 0 & مركز قضاء \\
\hline 1. & - & - & $1 \varepsilon$ & $r$ & ir & 1 & 11 & $r$ & - & - & - & - & ir & 1 & 11 & $\varepsilon$ & ناحية جصان \\
\hline$\Lambda$ & 1. & $\mu$ & 10 & 1 & 14 & 1 & - & - & - & - & - & - & - & - & IY & $r$ & ناحية زرباطية \\
\hline 117 & 0 & $\wedge$ & 9 & $v$ & $r$ & ir & $\varepsilon$ & 11 & $r$ & 17 & $r$ & IV & $r$ & 18 & r & r^ & مركز قضاء العزيزية \\
\hline$\leqslant \varepsilon$ & 11 & Y & 10 & 1 & $\mathrm{~V}$ & $\Lambda$ & $\Lambda$ & 7 & $\Lambda$ & 9 & 11 & V & $\mathrm{V}$ & 7 & 1. & 0 & ناحيةٌ الدبوني \\
\hline 79 & 7 & V & 14 & $r$ & 0 & 1. & 7 & $\Lambda$ & 7 & 11 & 7 & $1 Y$ & 0 & 9 & 9 & 7 & ناحية تاج الاين \\
\hline IVY & $r$ & ir & $r$ & 10 & r & rq & $r$ & rr & $r$ & rr & r & $\Gamma \varepsilon$ & 9 & $\varepsilon$ & 0 & ir & مركز قضاء \\
\hline rA & v & 7 & 9 & v & 11 & $\varepsilon$ & 1. & $r$ & Ir & $\varepsilon$ & Ir & 7 & $\Lambda$ & 0 & Ir & $r$ & ناحية الزبيدية \\
\hline$\varepsilon \Lambda$ & 9 & $\varepsilon$ & 11 & 0 & 1. & 0 & $\Lambda$ & 7 & $\Lambda$ & 9 & V & 11 & 1. & $r$ & 1. & 0 & ناحية الثحيمية \\
\hline $17 \leqslant \leqslant$ & - & $17 \varepsilon$ & - & IVY & - & $1 \wedge \varepsilon$ & - & 191 & - & $r . q$ & - & TYV & - & $r \leqslant 7$ & - & YO & المجموع \\
\hline
\end{tabular}

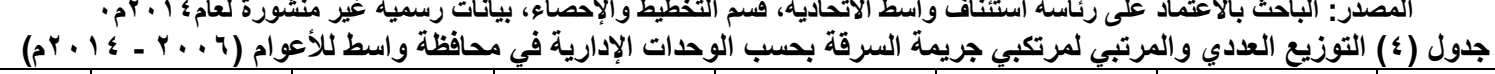

\begin{tabular}{|c|c|c|c|c|c|c|c|c|c|c|c|c|c|c|c|c|c|}
\hline \multirow[t]{2}{*}{ المجموع } & \multicolumn{2}{|c|}{$r .1 \leq$} & \multicolumn{2}{|c|}{$r .1 r$} & \multicolumn{2}{|c|}{$r .1 Y$} & \multicolumn{2}{|c|}{$r+11$} & \multicolumn{2}{|c|}{$r .1}$. & \multicolumn{2}{|c|}{$r \ldots q$} & \multicolumn{2}{|c|}{$r \ldots \Lambda$} & \multicolumn{2}{|c|}{$r \ldots r$} & \multirow{2}{*}{ لوحدات الإدارية } \\
\hline & المرتبة & العدد & المرتبة & العدد & المرتبة & العدد & المرتبة & العدد & المرتبة & العدد & المرتبة & العدد & المرتبة & العدد & المرتبة & العدد & \\
\hline$\leqslant r q \varepsilon$ & 1 & $\varepsilon \cdot r$ & 1 & $\{71$ & 1 & $\varepsilon r$. & 1 & $7 . r$ & 1 & $0 \wedge$. & 1 & 719 & 1 & זצי & 1 & $7 \leqslant 0$ & مركز قضاء \\
\hline rvo & $\varepsilon$ & rr & r & $\varepsilon \wedge$ & $\varepsilon$ & MI & $\mathrm{v}$ & $\leqslant 0$ & 7 & $\varepsilon r$ & 7 & $\varepsilon r$ & 7 & 71 & 0 & $V \varepsilon$ & ناحية شيخ سعد \\
\hline 119 & 11 & 11 & $\mathrm{~V}$ & $Y 1$ & 1. & 17 & $1 \varepsilon$ & IV & Ir & YY & Ir & $r \varepsilon$ & $\mathrm{V}$ & $\varepsilon$ & 9 & $r \wedge$ & ناحية واسط \\
\hline$\varepsilon \cdot \Lambda$ & $r$ & ro & 0 & ץ & $\wedge$ & $r_{1}$ & $\varepsilon$ & 71 & $\varepsilon$ & 00 & $\varepsilon$ & 7. & $r$ & vo & $r$ & VV & مركز قضاء \\
\hline IVT & 11 & 11 & $\mathrm{~V}$ & YI & $1 \varepsilon$ & 0 & $\Lambda$ & rY & 1. & $r q$ & 1. & 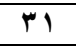 & 1. & $r r$ & $1 \pi$ & $r 1$ & ناحية الاحرار \\
\hline 01\{ & r & $\varepsilon V$ & $r$ & \&1 & $r$ & Or & r & $v^{\mu}$ & $r$ & 71 & r & Vr & r & VV & r & Ar & مركز قضاء \\
\hline
\end{tabular}




\begin{tabular}{|c|c|c|c|c|c|c|c|c|c|c|c|c|c|c|c|c|c|}
\hline & & & & & & & & & & & & & & & & & الحي \\
\hline $1 \leqslant 1$ & 1. & 14 & 11 & 11 & 1. & 17 & 11 & rV & 10 & 17 & 10 & IV & 11 & 19 & Ir & YY & ناحية البشائر \\
\hline IrV & Ir & 9 & Ir & 9 & 9 & IV & Ir & YY & 14 & 19 & 14 & YI & Ir & 17 & 10 & $1 \varepsilon$ & ناحية الموفقية \\
\hline 149 & $1 T$ & $\mathrm{~V}$ & $\Lambda$ & $r \cdot$ & Ir & 11 & $1 T$ & 11 & $1 \leqslant$ & IV & $1 \leqslant$ & 19 & $1 T$ & 11 & 1. & rq & مركز قضاء بلرة \\
\hline$V \leq$ & 10 & 0 & 14 & $\mathrm{~V}$ & 10 & $r$ & 17 & $\Lambda$ & IV & IY & 17 & $1 \varepsilon$ & 10 & 7 & $1 \leq$ & 19 & ناحية جصان \\
\hline$V V$ & $1 \varepsilon$ & 7 & $1 \leqslant$ & $\varepsilon$ & - & - & 10 & 11 & 17 & $1 \varepsilon$ & IV & 11 & $1 \leq$ & 9 & Ir & YY & ناحية زرباطية \\
\hline 4q & ir & 9 & $\varepsilon$ & $r v$ & 7 & $r r$ & $\bullet$ & or & 0 & $\leqslant 9$ & $\bullet$ & 04 & $\bullet$ & 79 & v & 10 & مركز قضاء \\
\hline YY & $\Lambda$ & 11 & 9 & 19 & $\mathrm{~V}$ & YY & 1. & YA & $\Lambda$ & rq & 9 & rY & 9 & $Y \xi$ & $\Lambda$ & $\leqslant 0$ & ناحية الابوني \\
\hline$Y \cdot \varepsilon$ & 0 & rY & 7 & YV & 0 & $r \cdot$ & 9 & 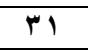 & 11 & YY & 11 & rq & Ir & 17 & 11 & $r r$ & ناحية تاج الدين \\
\hline$\varepsilon r q$ & V & 19 & $r$ & \&1 & $r$ & $r q$ & $r$ & 74 & $r$ & 71 & $\mu$ & IV & $\varepsilon$ & v. & $\varepsilon$ & VY & مركز قضاءة \\
\hline$r \leqslant 1$ & 7 & $r$. & 14 & $\mathrm{~V}$ & 11 & $1 \%$ & 7 & $\varepsilon 7$ & $\mathrm{~V}$ & $r \Lambda$ & $\mathrm{V}$ & $r q$ & $\Lambda$ & $r \mu$ & $\Lambda$ & $\varepsilon 0$ & ناحية الزبياية \\
\hline$Y \leq \varepsilon$ & 9 & 17 & 1. & IV & 14 & 9 & 1. & YA & 9 & ro & $\wedge$ & $r r$ & $\mathrm{~V}$ & $\varepsilon$ & 7 & 79 & ناحية الشحيمية \\
\hline$\Lambda N_{1} \leq$ & - & $77 \varepsilon$ & - & Aro & - & VYA & - & 1179 & - & $11 \%$ & - & $11 \wedge \wedge$ & & 1509 & - & $1+41$ & المجموع \\
\hline
\end{tabular}

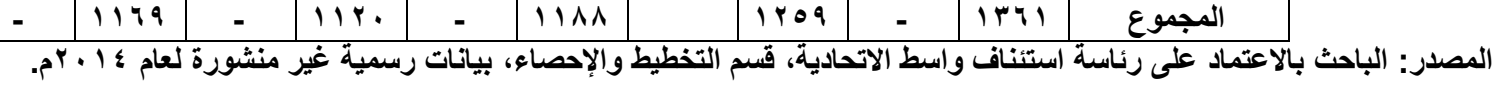


وبالحديث عن مرتكبات جريمتي القتل والسرقة فأنها شهدت تبايناً واضحاً في أعدادها طو ال مدة الدر اسـة وكما

$$
\text { يثير إلى ذلك الجدول(0) و(7) و وعلى النحو الأتي :- }
$$

ا - جاء مركز قضاء الكوت في المرتبة الأولى بالنسبة لمرتكبات جريمتي القتل والسرقة، حيث بلغت أعداد المتهمات

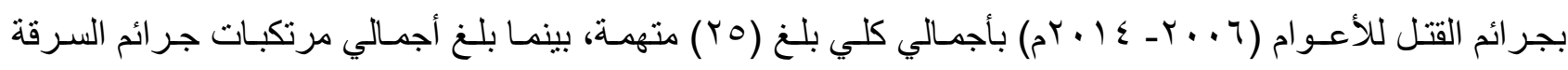
نحو) (r)

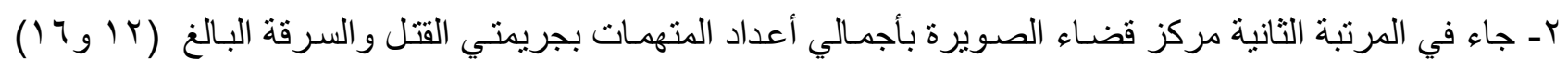
متهمة على التوالي . rـ أستحوذ مركز قضاء العزيزية و الحي على المرتبة الثالثة مناصفةً بأعداد المتهمات بجريمة القتل وبأجمـالي كلي بلغ . متهمات (V)

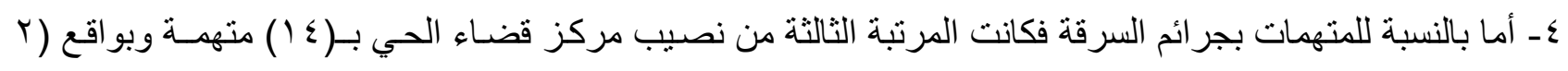



ه ـ تجدر الإشـارة إلى أن عدد من الوحدات الإداريـة قد خلت من جر ائم القتل والسرقة ولعدة أعوام كمـا هو الحسال

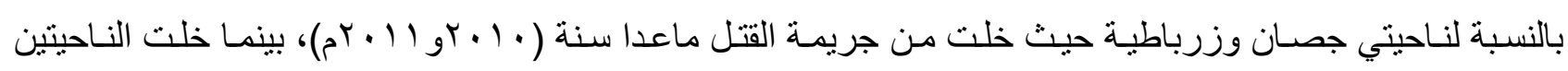

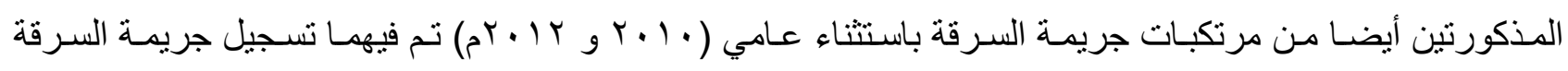
وبو اقع ( ب و I) ) متهمة على نو الي .

يستتنج من الاستقر اء السابق لمعطيات الجداول(r) و(ع) و و(0) و(؟) الخاص بمرتكبي جريمتي القتل والسرقة

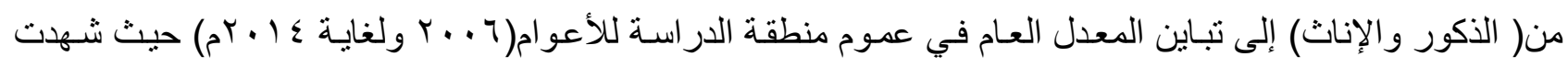

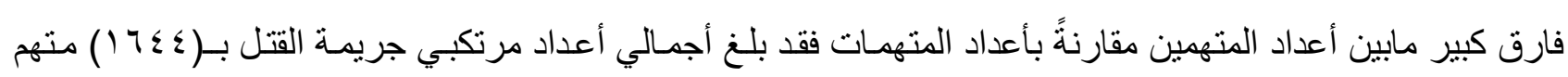

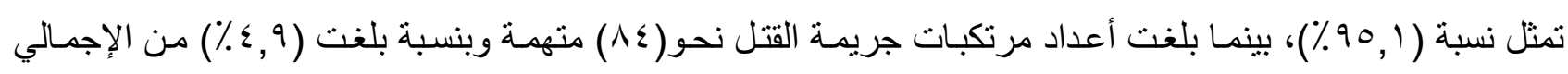
الكلي لجريمة القتل في عموم محافظة واسط ولكافة السنوات .

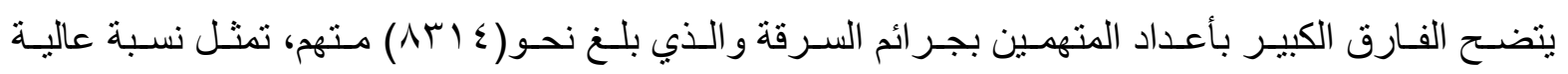

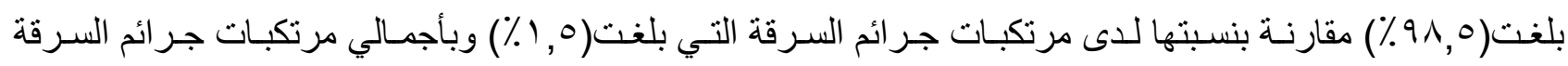






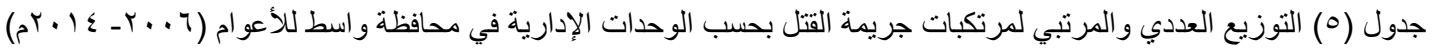

\begin{tabular}{|c|c|c|c|c|c|c|c|c|c|c|c|c|c|c|c|c|c|}
\hline \multirow{2}{*}{ ' لمجموع } & \multicolumn{2}{|r|}{ T.Iई } & \multicolumn{2}{|c|}{$r .1 T$} & \multicolumn{2}{|r|}{ T.IT } & \multicolumn{2}{|r|}{$r .11$} & \multicolumn{2}{|r|}{ r.1. } & \multicolumn{2}{|r|}{$r \ldots q$} & \multicolumn{2}{|r|}{$r \ldots 1$} & \multicolumn{2}{|c|}{ Y..T } & \multirow{2}{*}{ الوحدات الإدارية } \\
\hline & ل لمرتبة & ل ل لعدد & ل ل لمرتبة & ل لعدد & لمرتبة & لعدد & لمرتبة & لعدد & لمرتبة & لعدد & لمرتبة & لعدد & لمرتبة & لعدد & لمرتبة & لعدد & \\
\hline $\begin{array}{r}r \\
0\end{array}$ & & & & & & & & & & & & & & & & & مركز قضاء الكوت \\
\hline$r$ & & & & & & & & & & & & & & & & & ناحية شيخ سعد \\
\hline$r$ & & & & & & & & & & & & & & & & & ناحية واسط \\
\hline 0 & & & & & & & & & & & & & & & & & مركز قضاء النعمانية \\
\hline$\varepsilon$ & & & & & & & & & & & & & & & & & ناحية الاحر ار \\
\hline $\mathrm{v}$ & & & & & & & & & & & & & & & & & مركز قضاء الحي \\
\hline$r$ & & & & & & & & & & & & & & & & & ناحية البشائر \\
\hline$r$ & & & & & & & & & & & & & & & & & ناحية الموفقية \\
\hline$T$ & & & & & & & & & & & & & & & & & مركز قضاء بدرة \\
\hline 1 & & & & & & & & & & & & & & & & & ناحية جصان \\
\hline 1 & & & & & & & & & & & & & & & & & ناحية زرباطية \\
\hline$v$ & & & & & & & & & & & & & & & & & مركز قضاء \\
\hline$r$ & & & & & & & & & & & & & & & & & ناحية الدبوني \\
\hline
\end{tabular}






الصصدر: الباحث بالاعتماد على رئاسة استئناف واسط الاتحادية، قسم التخطيط و الإحصاء، بيانات رسمية غير منشورة لعام ؛ ا . بم.

جدول (?)

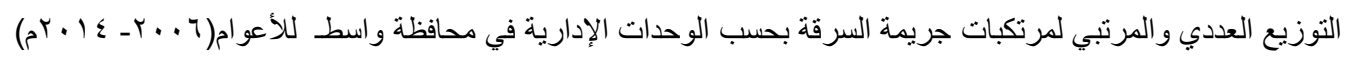

\begin{tabular}{|c|c|c|c|c|c|c|c|c|c|c|c|c|c|c|c|c|c|}
\hline \multirow[b]{2}{*}{ للجموع } & \multicolumn{2}{|r|}{ T.lई } & \multicolumn{2}{|r|}{$T \cdot 1 T$} & \multicolumn{2}{|c|}{$T \cdot I T$} & \multicolumn{2}{|r|}{$r .11$} & \multicolumn{2}{|r|}{ r.l. } & \multicolumn{2}{|c|}{$r \ldots q$} & \multicolumn{2}{|r|}{$r \cdots A$} & \multicolumn{2}{|c|}{$r \ldots T$} & \multirow{2}{*}{ الوحدات السنة } \\
\hline & لمرتبة & لعدد & لمرتبة & لعدد & لمرتبة & لعدد & لمرتبة & لعدد & لمرتبة & لعدد & لمرتبة & لعدد & لمرتبة & لعدد & لمرتبة & لعدد & \\
\hline$r$ & & & & & & & & & & & & & & & & & مركز قضاء \\
\hline$r$ & & & & & & & & & & & & & & & & & ناحية شيخ \\
\hline$r$ & & & & & & & & & & & & & & & & & ناحية واسط \\
\hline 1 & & & & & & & & & & & & & & & & & مركز قضاء \\
\hline
\end{tabular}




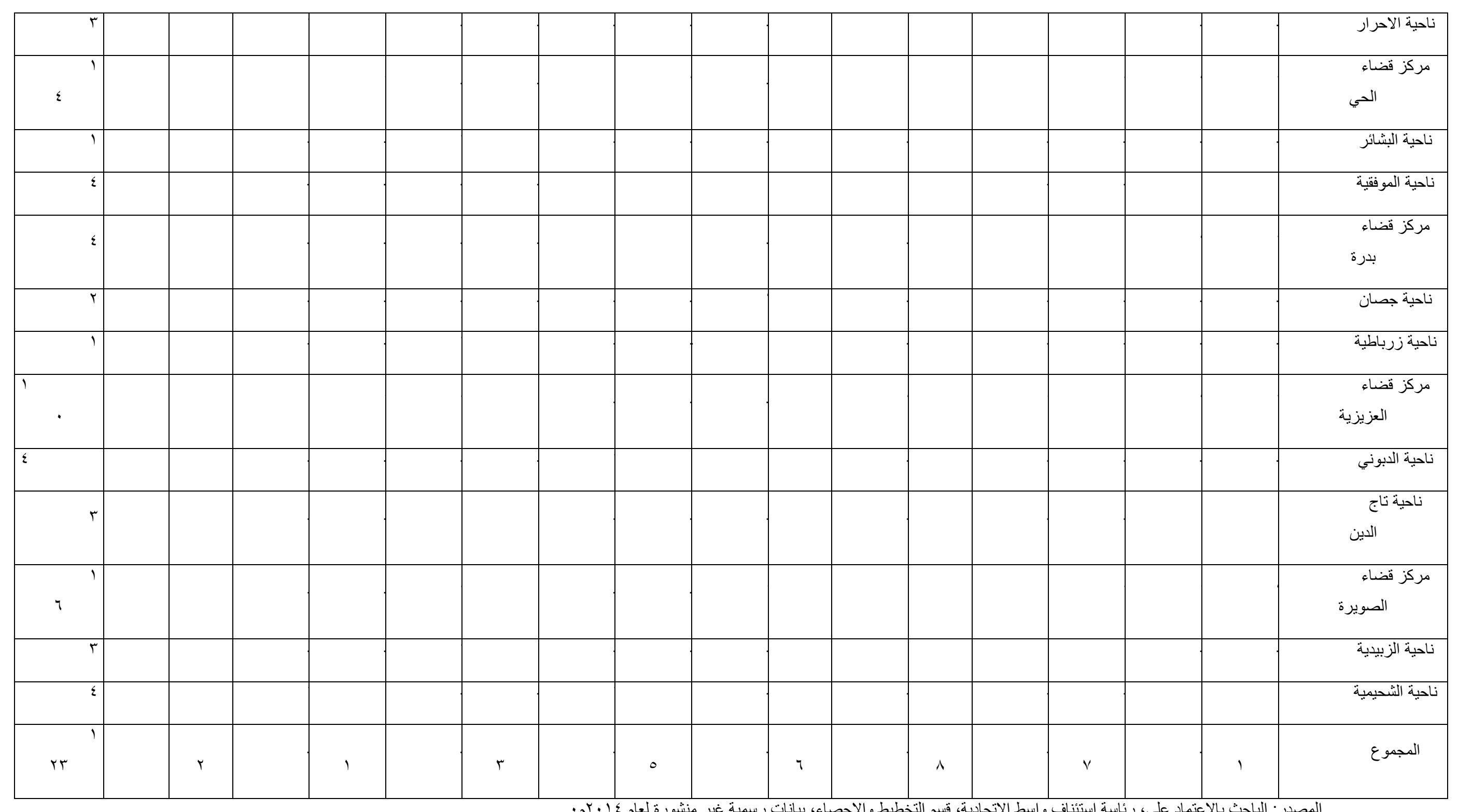

المصدر : الباحث بالاعتماد على، رئاسة استئناف واسط الاتحادية، قسم التخطيط والإحصاء، بيانات رسمية غبر منشورة لعام ؟ ا. بم. 


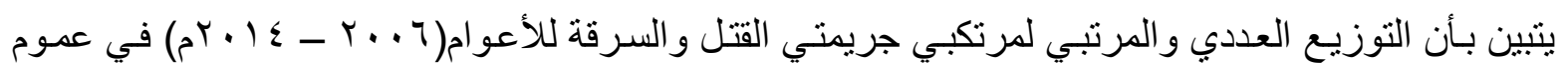
منطقة الدر اسة عن مدى التباين الكبير بأعداد مرتكبي الجرائم بحسب الوحدات الادارية ،آذ يمكن مشاهدة الفارق مـا بين

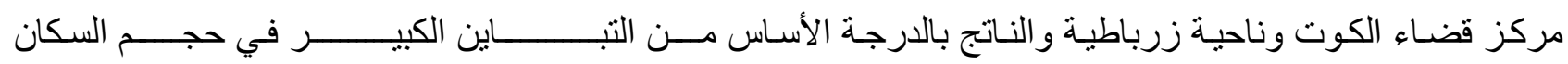

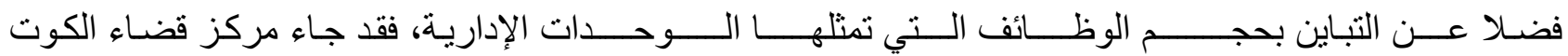

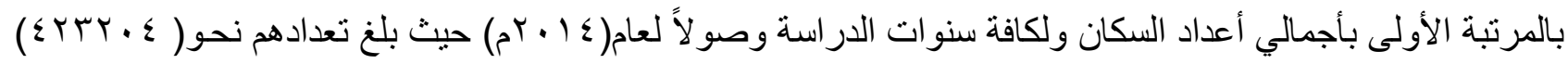

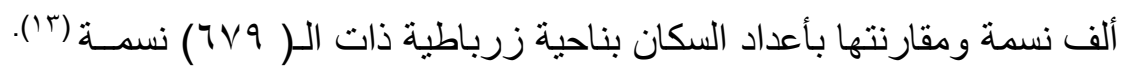
وباستخدام الدرجات المعيارية (*) (The Standard Marks) يمكن أن نميز من الجدول(Y)عدد من المستويات للتوزيع العددي(** ) لمرتكبي جريمني القتل و السرقة في محافظة واسط :أو لاًَ مرتكبى جريمة القتل:تثير الخريطة (r) لعام (T + . r م) إلى وجود ثلاث مستويات لمرتكبي جريمة القتل وهي :المستوى الأول : ( •, •-ـ فأكثر) :- ضَم هذا المستوى أعلى الوحدات الإداريـة بمرتكبي جريمـة القتل تمثلت بمركز



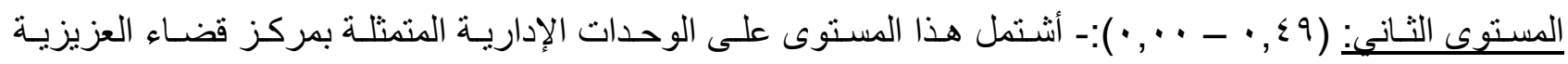
و النعمانية وبأعداد المتهمين بو اقع ( Y و و 9 ( ) متهم على التو الي.

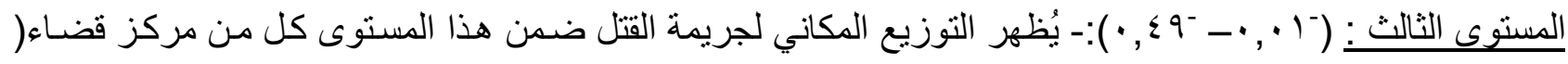
الصويرة و الحي وبدرة ) وبعدد المتهمين الذي بلغ ( ب او • ( و ه) منهم توالياً، بالاضافة إلى نواحي (الموفقيـة، البشائر، زرباطيـة، الزبيديـة، جصـان، الدبوني، الثـحيمية، تـاج الدين، الأحـرار، واسط ، وشيخ سـدل) وتراوحت فيهـا أعداد


المستوى الرابع: (־ 0, •- فأقل ):- لم يضم هذا المستوى أية وحدة إدارية . اما بالنسبة لعام ( • • rم) يُلاحظ من الخريطة (ع ) وجود أربع مستويات لمرتكبي جريمة القتل وهـي :-

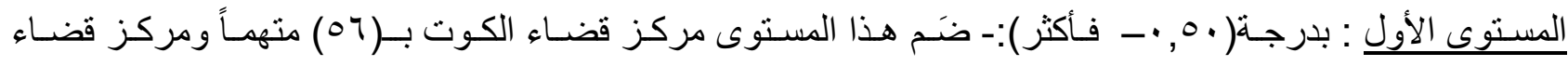
الصويرة بأجمالي عدد المتهمين البالغ (Yr) متهم. المستوى الثاني: (9 ؟, , - - , · ):- شمل هذا المستوى مركز قضـاء العزيزيـة والحي وبأجمـالي كلي بأعداد المتهمين

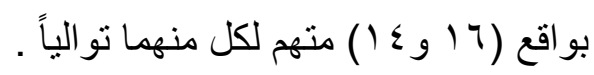
المستوى الثالث : ('ا •, •- - 9 ؛, • ):- يظهر ضمن هذا المسنتوى التوزيع المكاني لمرتكبي جريمـة القتل في مركز قضاء النعمانية ونواحي( الاحرار، تاج الدين، واسط ، الدبوني، والثحيمية). 
جدول (V) مرتكبي جريمتي القتل والسرقة حسب الوحدات الإدارية في محافظة واسط وبحسب الارجات المعيارية للأعوام († . . ؟(م)

\begin{tabular}{|c|c|c|c|c|c|c|}
\hline \multirow{2}{*}{\multicolumn{6}{|c|}{  }} & \multirow[b]{3}{*}{ الوحدات الإدارية } \\
\hline \multicolumn{2}{|c|}{ جريمة الســرقة } & & & جريمة القتـــــل & & \\
\hline Y. & $r+1$. & Y.. & $r \cdot 1 \leq$ & $r+1$. & $\begin{array}{ll} & \\
& \ldots Y\end{array}$ & \\
\hline$r, q \Lambda$ & $r, 9 v$ & $r, q 0$ & $r, 7$. & $r, r \mu$ & $r, q$ & مركز قضاء الكوت \\
\hline$\cdot 11$ & $\cdot, 11$ & $\cdot, \cdot 0$ & $\cdot, \cdot r$ & $v, \varepsilon$. & $\cdot, \cdot \varepsilon$ & ناحية شيخ سعد \\
\hline$\cdot, \mu_{1}$ & $\cdot, \Gamma \varepsilon$ & $\cdot, r$. & $\cdot, \mathrm{TV}$ & $\cdot, r_{q}$ & $\cdot, Y_{4}$ & ناحية واسط \\
\hline$\cdot, 17$ & $\cdot, \cdot 9$ & $\cdot, \cdot r$ & $\cdot, 70$ & $\cdot, 1 \mu$ & $\cdot, 17$ & مركز قضاء النعمانية \\
\hline$\cdot, r_{1}$ & $\cdot$, , 9 & $\cdot, \leqslant \varphi$ & $\cdot, M_{1}$ & $\cdot, Y_{1}$ & $\cdot, r \cdot$ & ن احية الاحرار \\
\hline$\cdot, \cdot 9$ & $\cdot, \cdot r$ & $\cdot, \cdot r$ & $\cdot, \cdot r$ & $\cdot, \cdot r$ & $\cdot, 11$ & مركز قضاء الحي \\
\hline$\cdot, r 9$ & $\cdot, 49$ & $\cdot, \leqslant 1$ & $\cdot, r$ & $\cdot, 0 Y$ & $\cdot, \leqslant \leqslant$ & ناحية البشائر \\
\hline 西, & $\cdot, r v$ & $\cdot, \leqslant \leqslant$ & $\cdot, 0$. & $\cdot, \mathrm{TV}$ & $\cdot, \leqslant \wedge$ & ن احية الموفقية \\
\hline$\cdot, \mu_{0}$ & $\cdot$, rᄉ & $\cdot, r \wedge$ & $\cdot, 79$ & $\cdot, 9$. & $\cdot, r v$ & مركز قضاء بدرة \\
\hline$\cdot, \mathrm{rA}$ & $\cdot, \leqslant r$ & $\cdot, \leqslant \mu$ & - & - & $\cdot, \leqslant 1$ & ناحية جصان \\
\hline$\cdot, r v$ & $\cdot, \ldots$ & $\cdot, \leqslant 1$ & $\cdot, 79$ & - & • & ن ن احية زرباطية \\
\hline • & $\cdot, 1 \pi$ & $\cdot, 11$ & $\cdot, r^{\prime}$ & $\cdot, 11$ & $\cdot, \leqslant 9$ & مركز قضاء العزيزية \\
\hline$\cdot, r \mu$ & $\cdot, r \mu$ & $\cdot, r_{0}$ & $\cdot, \mathrm{VA}$ & $\cdot$ & $\cdot, r v$ & ناحية الدبوني \\
\hline$\cdot, 19$ & $\cdot, \mu_{1}$ & $\cdot, \leqslant \cdot$ & $\cdot, r$ & $\cdot, r^{1}$ & • & 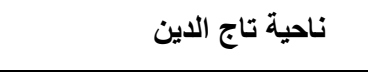 \\
\hline$\cdot$, , r & $\cdot, \cdot \varepsilon$ & $\cdot, \cdot r$ & $\cdot, r v$ & $1, \varepsilon$. & $\cdot, 11$ & مركز قضاء الصويرة \\
\hline$\cdot, r 1$ & $\cdot, r r$ & $\cdot, r_{0}$ & $\cdot, \xi \cdot$ & $\cdot, \mathrm{V} \leqslant$ & $\cdot, \leqslant \leqslant$ & ناحية الزبيدية \\
\hline • & $\cdot, r \varepsilon$ & $\cdot, 1$ & $\cdot, 09$ & ד & $\cdot, r v$ & ناحية الثحيمية \\
\hline $\begin{array}{r}r q \\
1\end{array}$ & 10,1 & A. & $1 \cdot$, & IT, & $1 \quad \leq, 9$ & الوسط الحسابي \\
\hline 91,0 & 199 & $1 \leqslant r$ & 1., & IT, & $r v, 1$ & الانحراف المعياري \\
\hline
\end{tabular}

المصدر: الباحث بالاعتماد على بيانات الجدول (ب و ؛) ·

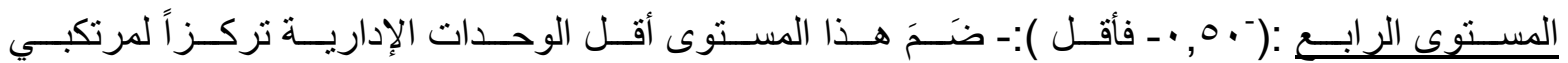
جريمة القتل وشمل مركز قضاء بدرة بالإضافة إلى نواحي( الزبيديـة، الموفقيـة، البشـائر وشيخ سعد) وتر اوحت أعداد مرتكبي جريمـة القتل مـابين(r- ^) متهم ـ فيما خلت نـاحيتي (زرباطية وجصـان) من الدرجات المعياريـة لأنهــا لم تسجل فيهما أي جريمة قتل في العام ( • • ( مج) . 
خريطة (r) التوزيع الجغر افي لأعداد مرتكبي جريمة القتل بحسب الوحدات الإدارية في محافظة واسط لعامج +. rم

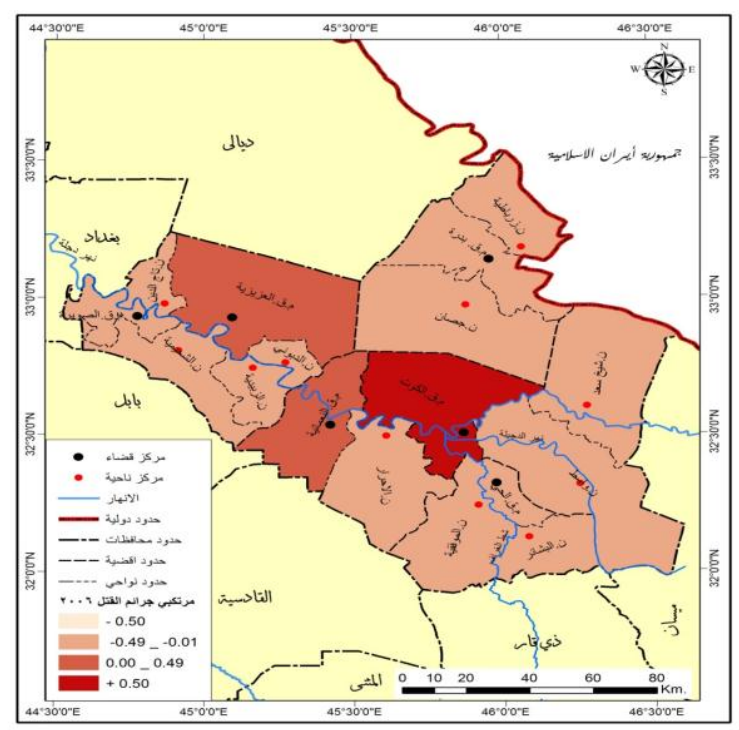

المصدر :الباحث بالاعتماد على جدول (Yv) .

خريطة (ع) التوزيع الجغر افي لأعداد مرتكبي جريمة القتل بحسب الوحدات الإدارية في محافظة

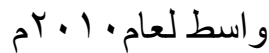

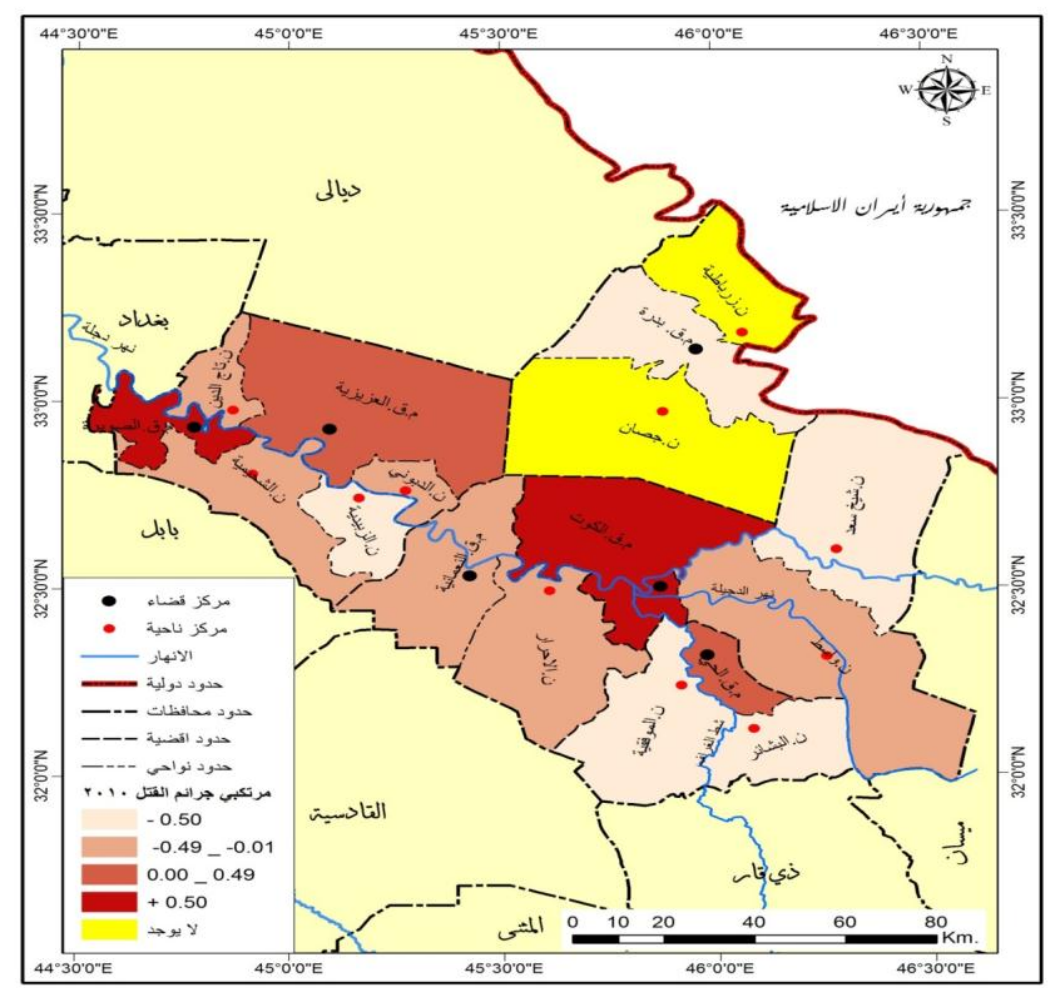

المصـــــر : الباحـــث

بالاعتماد على جدول (V) - (V) 
اما بخصوص عام(ع ( • rم) فَتُظهر الخريطة(0) أربع مستويات لمرتكبي جريمة القتل و على النحو الاتي:المستوى الأول : ( •., •- فأكثر) :- حَاز فيها مركز قضاء الكوت على المرنبة الاولى بو اقع كلي بلغ (^ء) متهماً ثم مركز قضاء النعمانية في المرتبة الثانية بمجموع ( V V ( ) متهم.

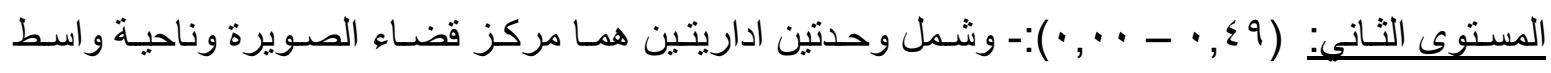
وبو اقع كلي بلغ ( T ا ) متهم لكل منهما . خريطة (0) التوزيع الجغر في لأعداد مرتكبي جريمة التنل بحسب الوحدات الإدارية في محافظة واسط لعامع ا بـ م

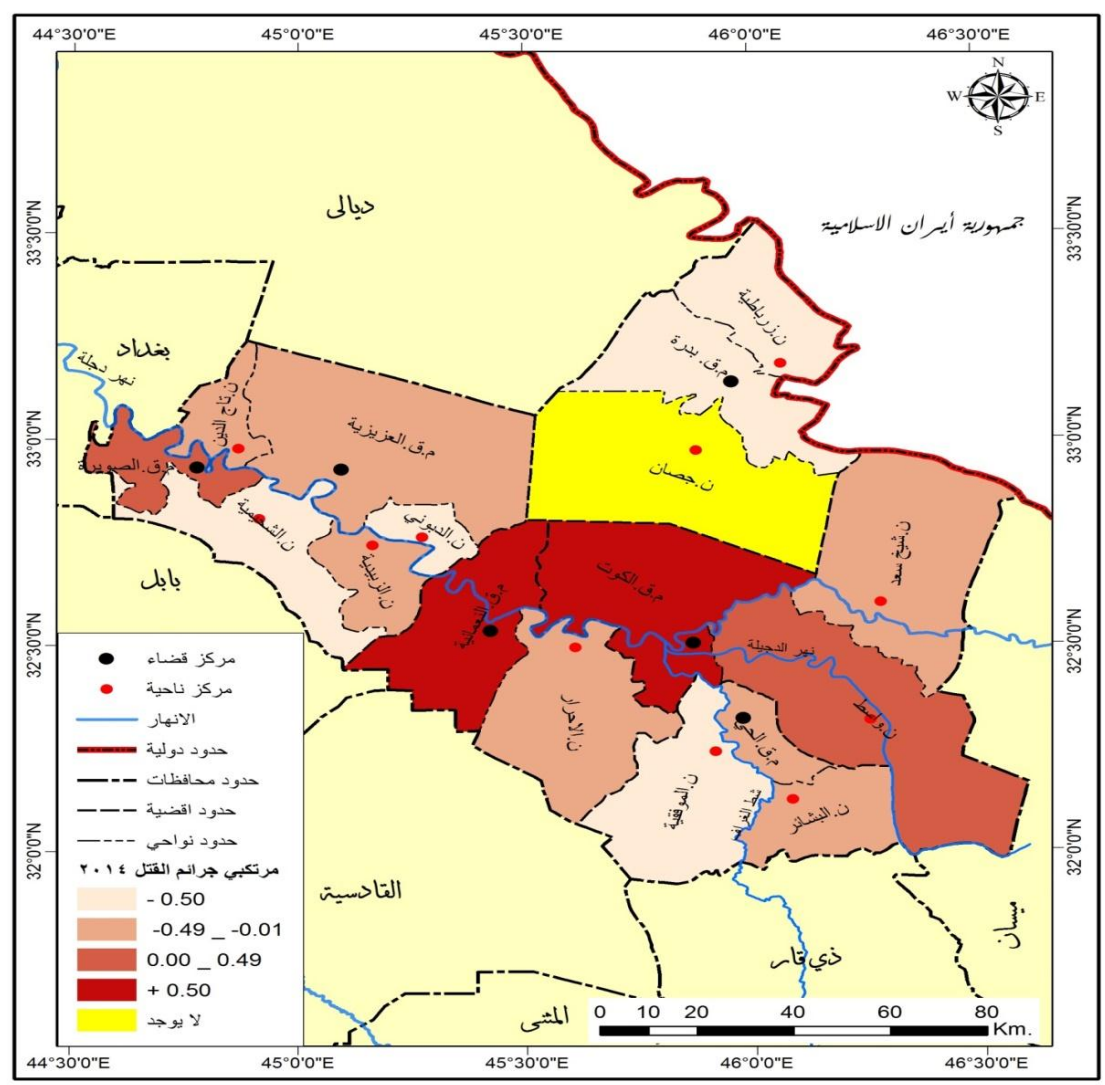

المصدر: الباحث بالاعتماد على جدول (V) .

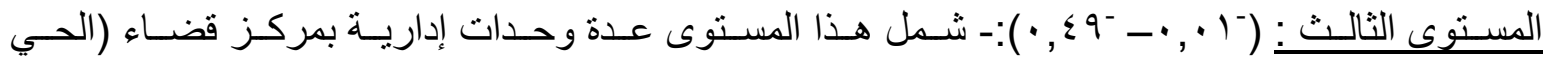

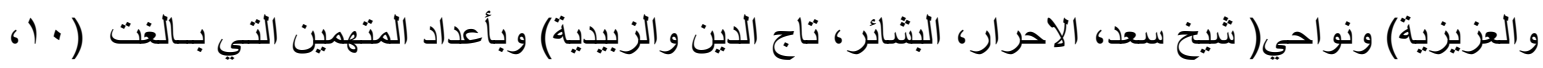

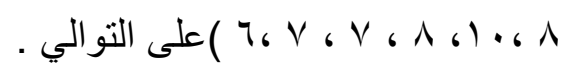

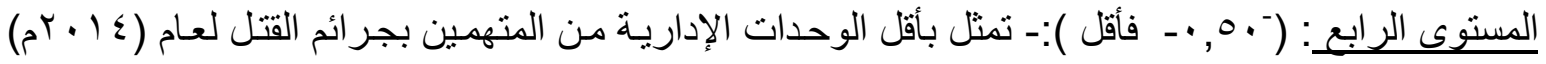

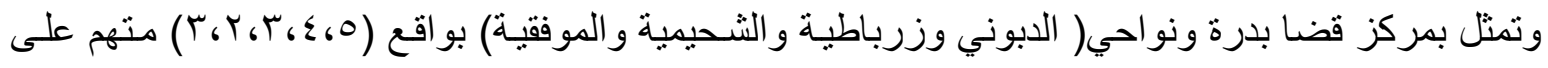
التو الي، فيما خلت ناحية جصان من الدرجات المعيارية ولم تسجل اي جريمة قتل لعام(ع ا • بم) 
ثثانياً- مرنكبي جريمة السرقة:-

يبرز الجدول(V)عدة مستويات لتوزيع مرتكبي جريمة السرقة كما يلاحظ من الخريطة (؟) لعام( T + . rم):



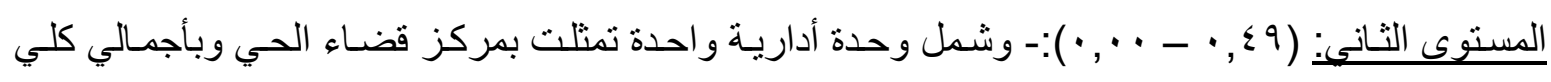
بأعداد المتهمين بـ(N) متهم .

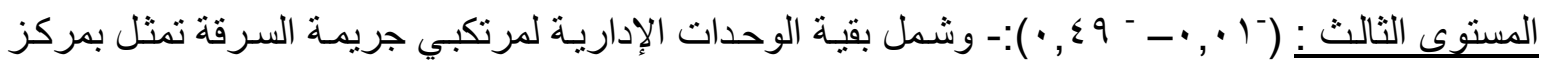

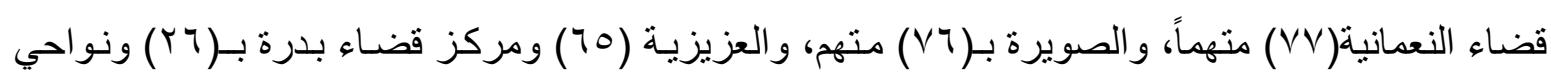

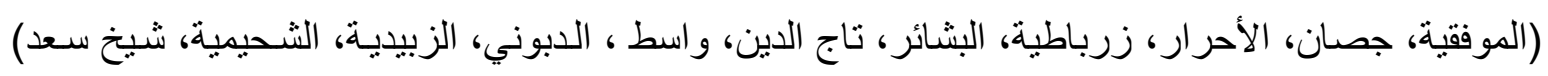

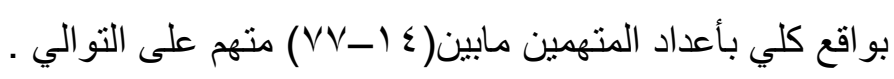
المستوى الرابع: (- .0, · - فأقل ):- لم يتمثل هذا المستوى في أية وحدة إدارية . خريطة (؟) التوزيع الجغر افي لأعداد مرتكبي جريمة السرقة بحسب الوحدات الإدارية في محافظة واسط



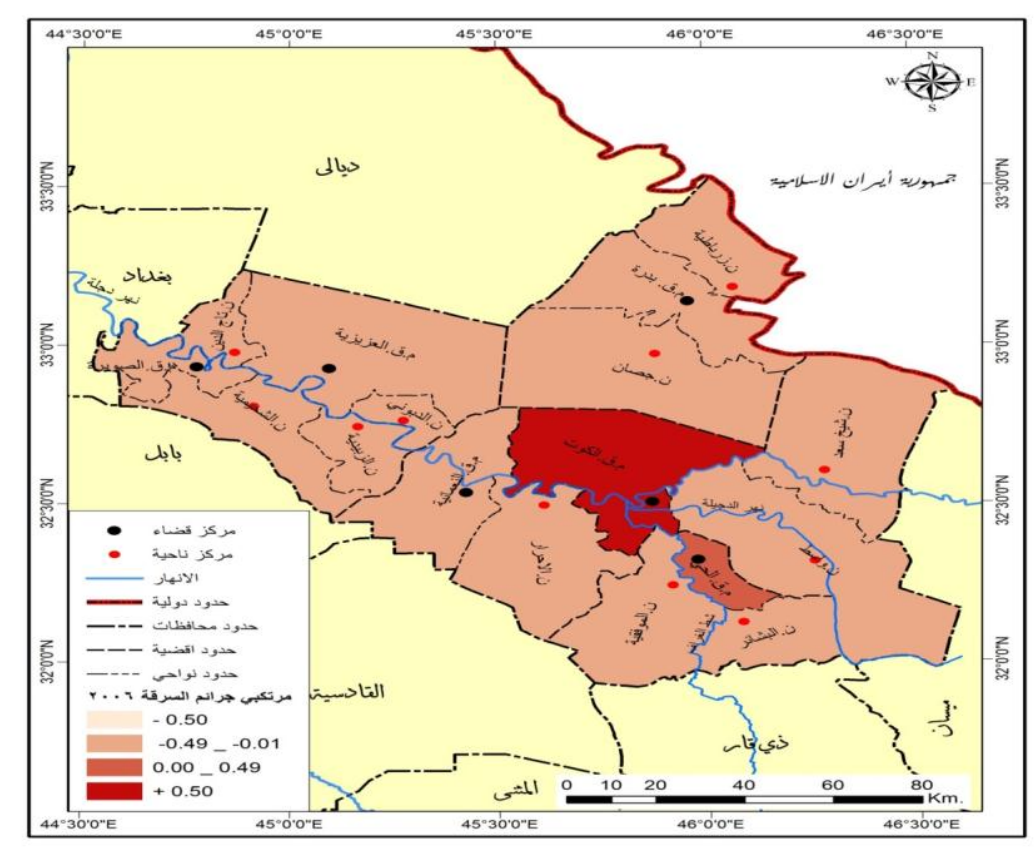

المصدر: الباحث بالاعتماد على جدول (V) . (V)

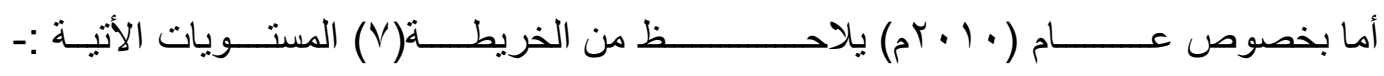
المستوى الأول: ( (0, •- فأكثر) :- تمثل بمركز قضاء الكوت على أعلى جرائم السرقة بـ( • هـ) متهم .

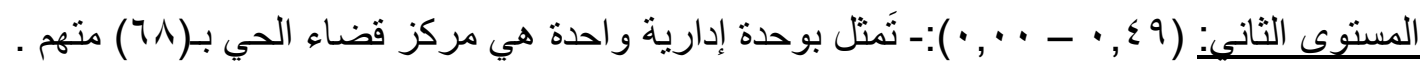



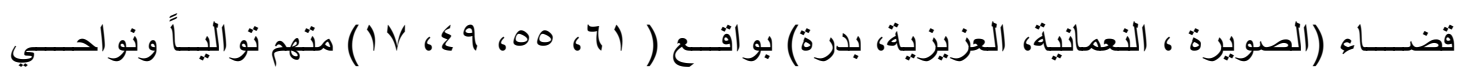


( شيخ سعد، الزبيدية، الدبوني، الثحيمية، الأحرار، تاج الدين، واسط ، الموفقية، البشـائر، زرباطية ،جصـان) وبأجمالي كلي بأعداد المتهمين بين(r ع- ب ا ) متهم . المستوى الرابع: (--0, · - فأقل ):- لم يضم هذا المستوى أي من الوحدات الإدارية بمنطقة الدراسة .

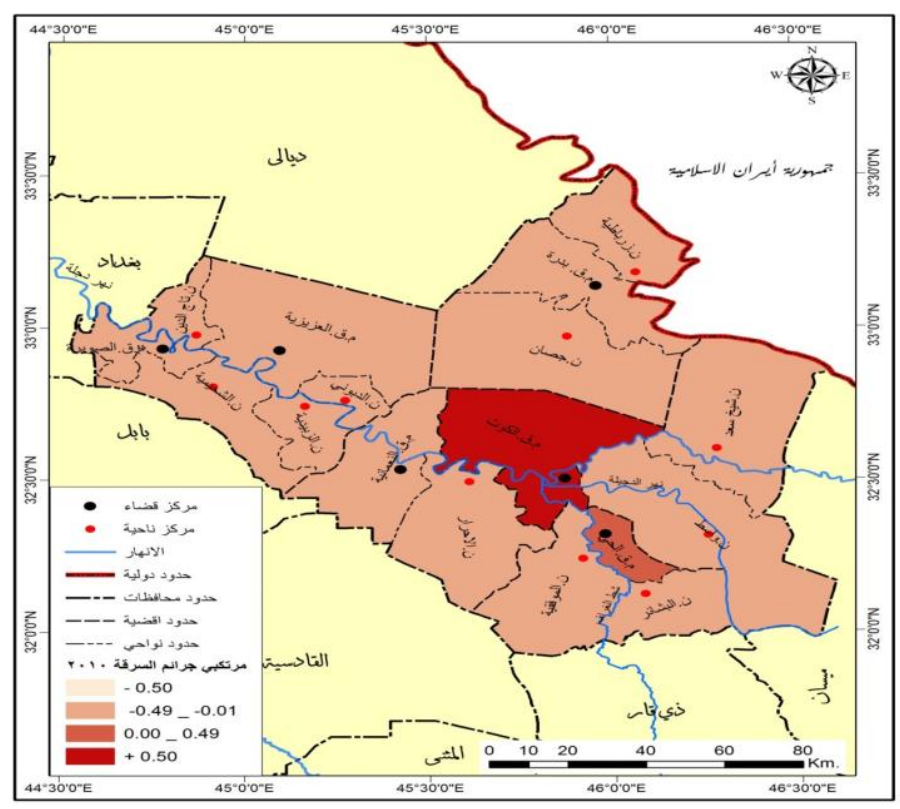

$$
\begin{aligned}
& \text { خريطة (Y)التوزيع الجغر افي } \\
& \text { لأعداد مرتكبي جريمة السرقة بحسب }
\end{aligned}
$$

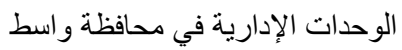

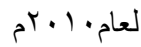

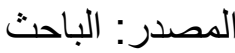

بالاعتماد على جدول (V) - (V)

أما بالنسبة لعام (ع ( • بم) فيلاحظ من الخريطة(^) عدة مستويات معيارية على النحو التالي:المستوى الأول : (••, · - فأكثر) :- يضم أكثر الوحدات الإدارية تركز ا بأعداد المتهمين بجر ائم السرقة في عموم منطقة الدر اسة تمثلت بمركز قضاء الكوت بو اقع (r • ع) متهم .



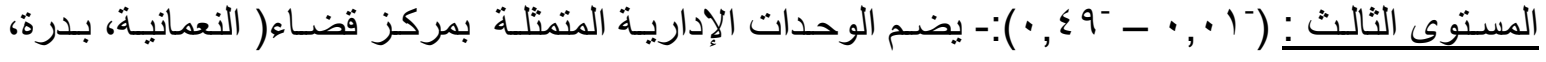
العزيزية، الصويرة) بالإضافة إلى نواحي(شيخ سعد، الأحرار، واسط ، الموفقية، البثـائر، جصـان، زرباطية ، الدبوني، تاج الدين، الزبيدية، الثحيمية،) وتراوح عدد المتهمين ما بين(0_ ب ب) متهم . المستوى الرابع: (-•. . •- فأقل ):- لم يتمثل في هذا المستوى أي من الوحدات إدارية . 


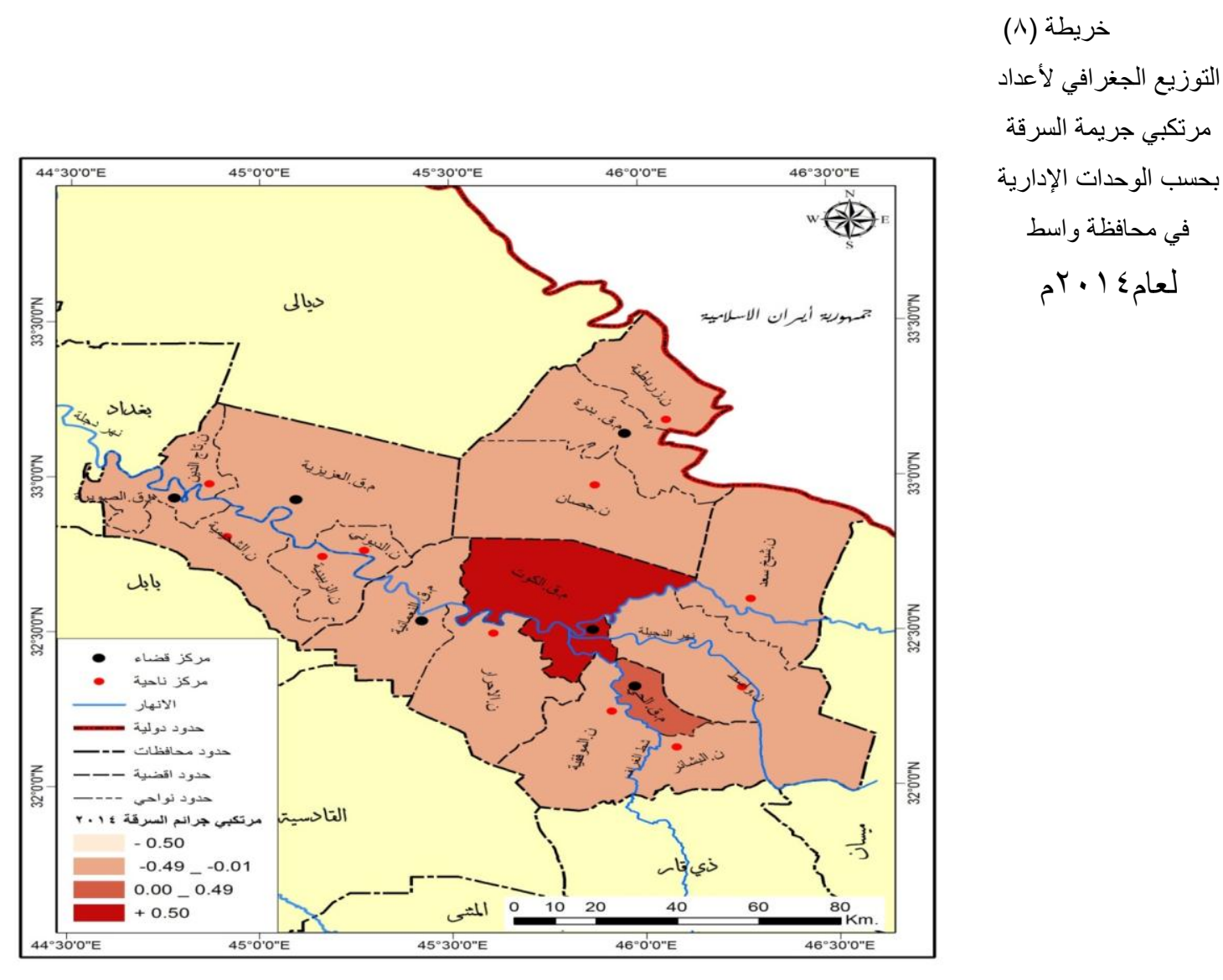

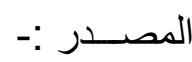

الباحث بالاعتماد على جدول(V) . (v) .

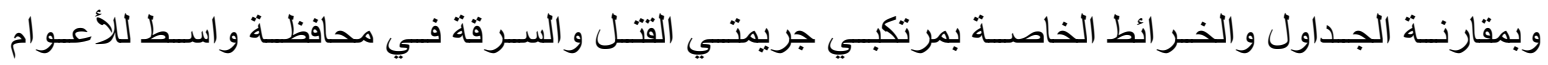

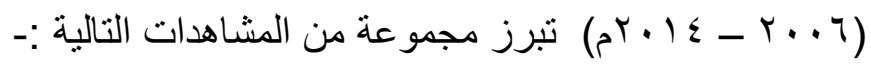

ـ تميز بعض الوحدات الإداريـة بمستوى ثابت كمـا هو الحسال بالنسبة لمركز قضـاء الكوت، حيث أنفرد

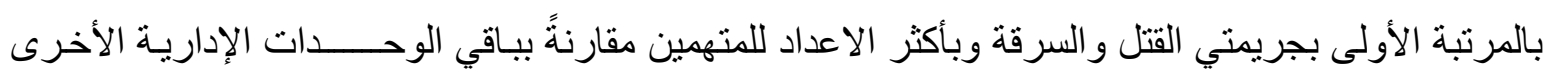

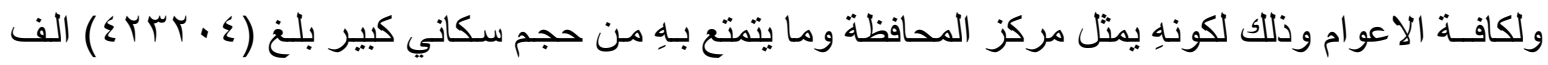


أعداد المتهمين بجريمتي القتل و السرقة ويرجـــع ذلك الــــى انخفاض الحجم السكاني بشكل واضح كمـا هو

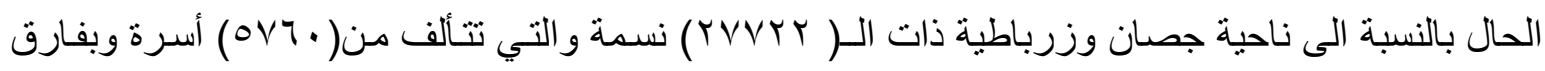


ـ أستحواذ مركز قضاء الصويرة على المرتبة الثانية بالنسبة لمرتكبي جريمـة القتل وبأجمـالي كلي بـ( VYT) متهم، تناهُ كل من مركز قضاء النعمانية و العزيزية بالمرتبة الثالثة و الر ابعة بأعداد مرتكبي جرائم القتل بو اقع .

- حاز مركز قضاء الحي على المرتبـة الثانية بالنسبة لمرتكبي جريمـة السرقة وبمجموع كلي بلـغ بــ( (0)

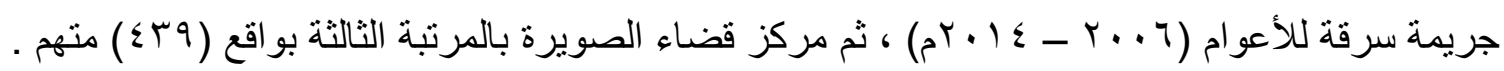


يُعزى السبب الرئيس بارتفاع معدلا ت الجر ائم بهذهِ الوحدات الإداريـة نظر اً لمـا تتمتع بـهِ مـن حجم

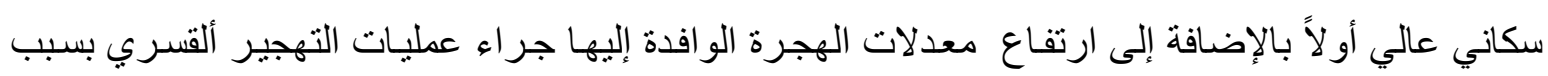
تردي الوضع الأمني في عدد من المحافظات المجاورة ولكون هذهِ المحافظسات الجنوبيـة تشهـ استقرار نسبي

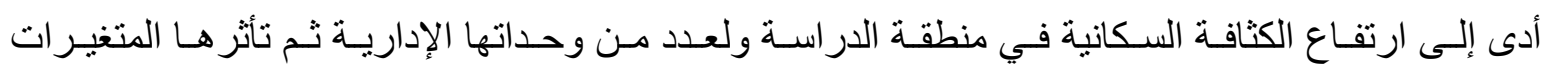

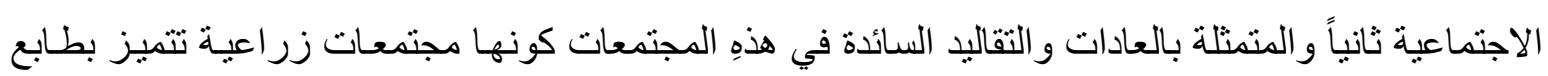
ريفي يفرض عليها عادات وتقاليد ونمط معيشة خاضع للنظم العشائرية و التعصب القبلي . ـ نتـير خـر ائط التوزيـع العددي السـابقة بـأن المستوى الثالث للـدرجات المعياريـة لمرتكبـي جريمتـي القتل

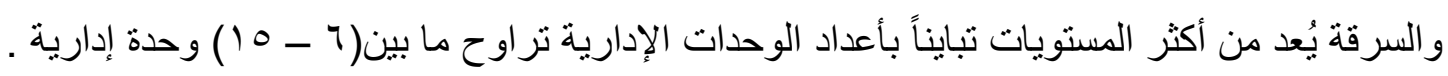
ـ نالت المر اتب الأخيرة بأعداد المتهمين بجريمتي القتل و السرقة كل من مركز قضـاء بدرة ونـاحيتي (جصـان

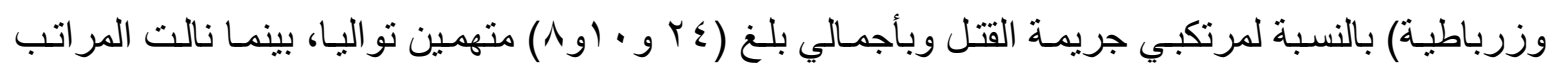



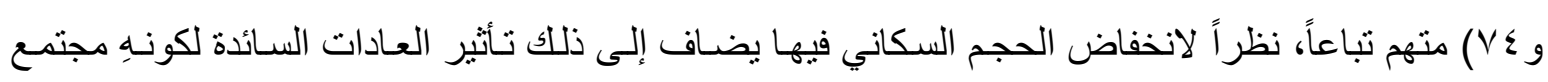
ريفي يُعد جرائم السرقة من الأمور المعيبة في المجتمع، يضاف إليهِ عامل أخر يتمثل بعلاقات اجتماعيـة جيدة

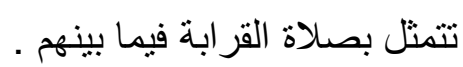
وباستخدام الدرجات المعياريـة يُلاحظظ مـن الجدول(^) عدة مسـتويات للتوزيـع العـدي لمرتكبـات


أو لاًَ- مرنكبات جريمة القتل:-

تشير الخريطة(9) الخاصة بمرتكبات جريمة القتل العسام(؟ + . r م) الى وجود المستويات الاتبة:-

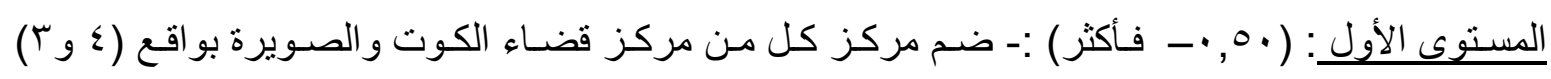

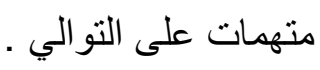



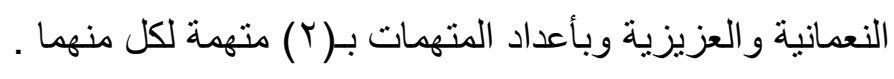

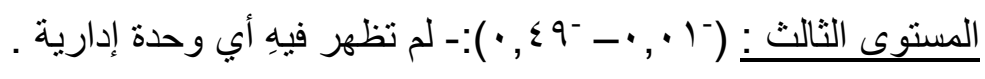

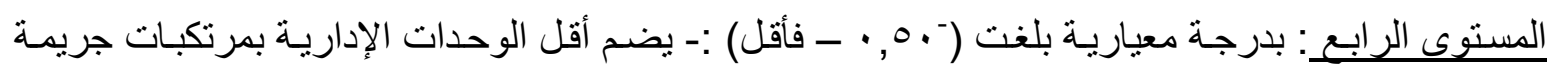
القتل والتي تتمثل بمركز قضاء( الحي) ونواحي(شيخ سعد، و اسط ، الدبوني ) بو اقع متهمة واحدة لكل منها، أخذين بنظر الاعتبار عدم ظهور عدد من الوحدات الإدارية وخلو ها من المتهمات بجرائم القتل .


المستوى الأول:( ••, •-ـ فأكثر): جاء فيهِ مركز قضاء الكوت بالمرتبة الأولى بأعداد المتهمات بجريمـة القتل

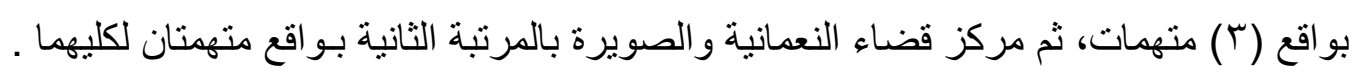


المستوى الثاني: ( 9 §, •- · ·, • •):- لم تتمثل فيهِه الوحدات الادارية .

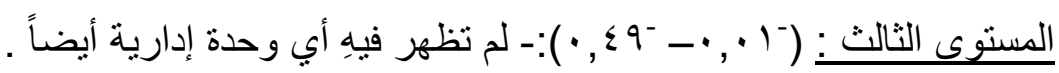

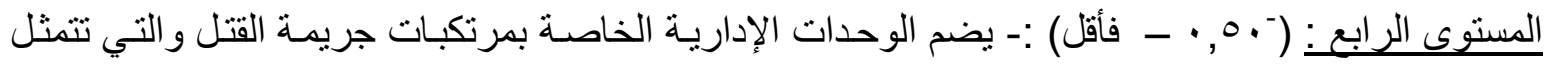
بنواحي (شيخ سعد، الأحرار، جصان، الثحيمية) بو اقع متهمة لكل منها .

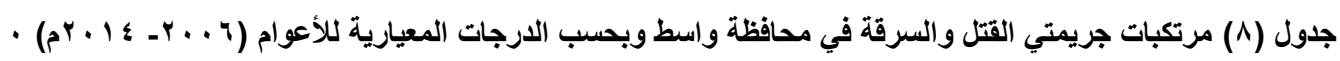

\begin{tabular}{|c|c|c|c|c|c|c|}
\hline \multicolumn{6}{|c|}{ الدرجــــــات المعيــــــــارية } & \multirow[b]{3}{*}{ الوحدات الإدارية } \\
\hline & جريمة الســ & & & جريمة || & & \\
\hline r. $\quad$ Is & $\begin{array}{ll}r+1.1 & \\
& \end{array}$ & $\begin{array}{ll}+. \cdot & \\
& \end{array}$ & q.1 & $\begin{array}{lll} & & \\
& .1 .\end{array}$ & $\begin{array}{l}r \\
\end{array}$ & \\
\hline $1, \lambda r$ & $r, r \cdot$ & r, rq & $r, r$. & 5,10 & r & مركز قضاء \\
\hline- & - & $\cdot, \mathrm{Vq}$ & - & $\cdot, V Y$ & $\cdot, \mathrm{V} r$ & ناحية شيخ سعد \\
\hline- & - & - & - & - & $\cdot, \mathrm{V} \mu$ & ن ناحية واسط \\
\hline . & $\cdot, r$. & $\cdot, \cdot \wedge$ & - & $\cdot, V Y$ & $\cdot, 19$ & مركز قضضاء \\
\hline- & - & - & $1^{-}$ & $\cdot, \mathrm{VY}$ & - & ن احية الاحرار \\
\hline$\cdot, 91$ & - & $\cdot, \cdot \wedge$ & $\cdot, \mathrm{IV}$ & - & $\cdot, \mathrm{V} \mu$ & مركز قضاء الحي \\
\hline- & - & - & - & - & - & ناحية البشائر \\
\hline- & $\cdot, \wedge$. & $\cdot, \mathrm{Vq}$ & $1^{-}$ & - & - & ناحية الموفقية \\
\hline- & - & $\cdot, \cdot \wedge$ & - & - & - & مركز قضاء بدرة \\
\hline - & $\cdot, r$. & - & - & $\cdot, V_{Y}$ & - & ناحية جصان \\
\hline- & - & - & - & - & - & ناحية زرباطية \\
\hline$\cdot, 91$ & - & $\cdot, \cdot \wedge$ & - & - & $\cdot, 19$ & مركز قضاء العزيزية \\
\hline$\cdot, 91$ & $\cdot, \wedge$. & - & - & - & $\cdot, \mathrm{V \mu}$ & ناحية الدبوني \\
\hline- & - & $\cdot, \mathrm{\vee} 9$ & - & - & - & ناحية تاج الدين \\
\hline.,+ 91 & $\cdot, r \cdot$ & $\cdot, 70$ & $1^{\circ}$ & $\cdot, \mathrm{Vr}$ & $1, .9$ & مركز قضاء \\
\hline- & - & - & - & - & - & ناحية الزبيدية \\
\hline - & - & $\cdot, \mathrm{V} 9$ & - & $\cdot, \mathrm{Vr}$ & - & ناحية الثحيمية \\
\hline r & $r, \uparrow$ & r, & $r, r$ & , & 1 & الوسط الحسابي \\
\hline 1,1 & r & $1, \varepsilon$ & $1, r$ &, $\mathrm{v}$ & 1 & المعياري الانحرافت \\
\hline
\end{tabular}

المصدر : الباحث بالاعتماد على بيانات الجدول (ه و $).$ 


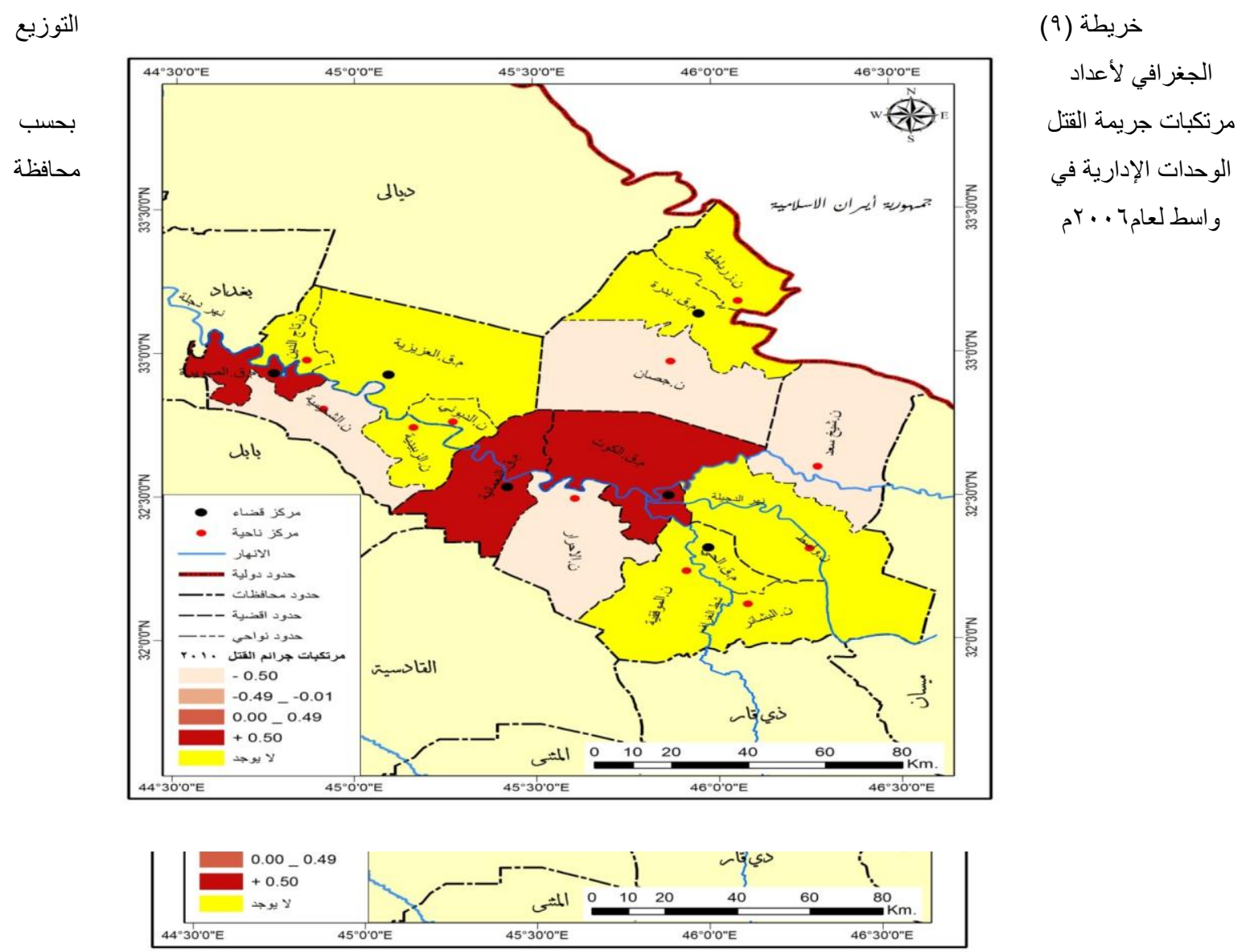

المصدر :- الباحث بالاعتماد على جدول(^) . . (1)

كما ويلاحظ من الخريطة( • () عدم وجود للوحدات الإدارية ضمن المستوى الثاني و الثالث بالإضـافة

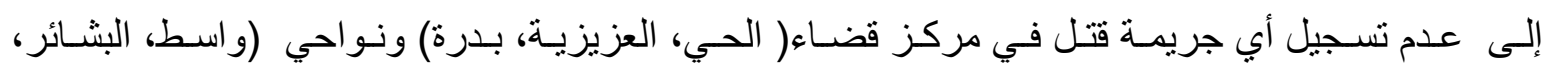
الموفقية، الدبوني، تاج الدين، الزبيدية وزرباطية) لعام ( • • ب جم) . خريطة (• (1) التوزيع الجغر افي لأعداد مرنكبات جريمة القتل بحسب الوحدات الإدارية في

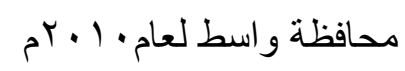

المصدر :- الباحث بالاعتماد على جدول(^) .

وتثير خريطة (1) (1) لعام( ـ ( ـ r م) الخاصة بالمتهمات بجريمة القتل الى المستويات الآتية :المستوى الأول : ( •, •-- فأكثر):- تمثل بمركز قضاء الكوت فقط بأعداد المتهمات بـ(ع) متهمات . المستوى الثاني: ( 9 ـ, • - · , • ):- لم تسجل في هذا المستوى اي من الوحدات الإدارية .

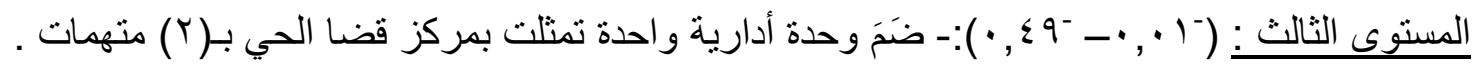
المستوى الر ابع : (-- . , • - فأقل ):- يتألف من ثلاث وحدات أداريـة تمثلت بمركز قضـاء الصويرة ونـاحيتي الأحر ار و الموفقية بو اقع متهمة واحدة لكل منها . 
خريطة ( (1) التوزيع الجغر افي لأعداد مرتكبات جريمة التتل بحسب الوحدات الإدارية في محافظة واسط لعامـ ا بrم



المصدر :- الباحث بالاعتماد على جدول(^) . - (ال

ثانياً- مرنكبات جريمة السرقة:-

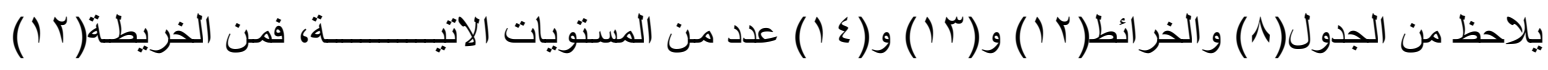

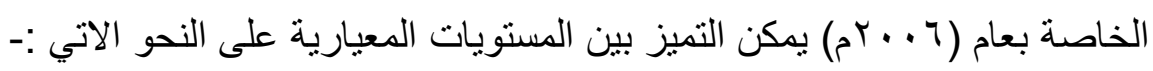

المستوى الأول : بدرجة (·, ·- - فأكثر) :- حاز فيها مركز قضاء الكوت بـأعلى معدلات السرقة بـو اقع(؟)

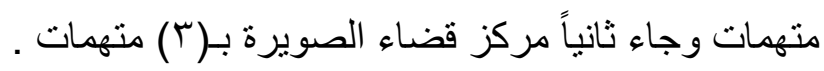

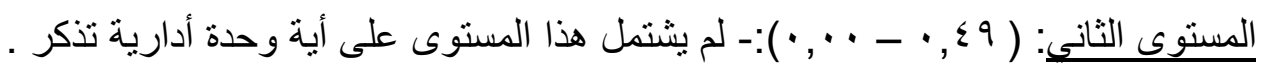

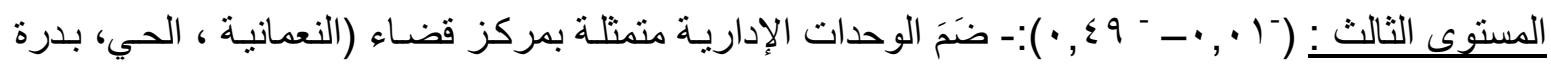

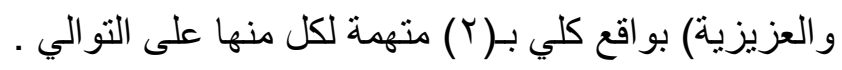


خريطة (r ا ) التوزيع الجغر افي لأعداد مرتكبات جريمة السرقة بحسب الوحدات الإدارية في محافظة واسط

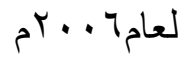

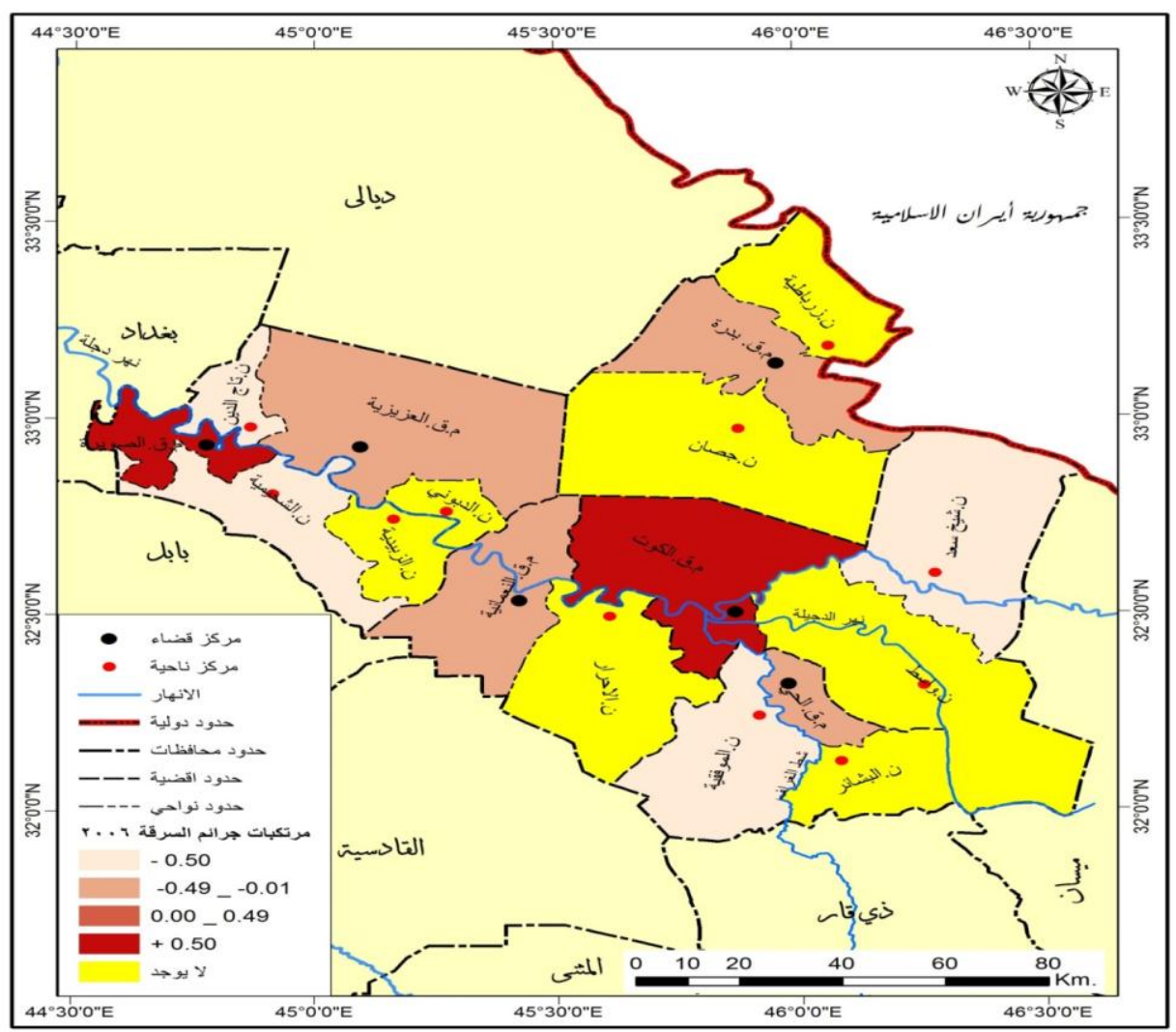

المصدر :- الباحث بالاعتماد على جدول(^) . (1) - (ل)

أما بالنسبة لعام ( • • r م) فيُلاحظ من الخريطة (r ا ) المستويات الاتيــــــة :-

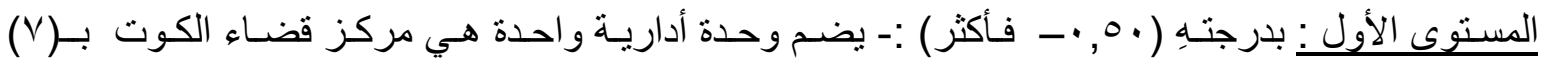
متهمات

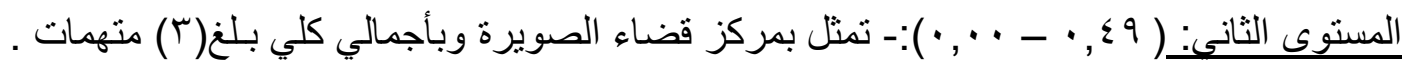

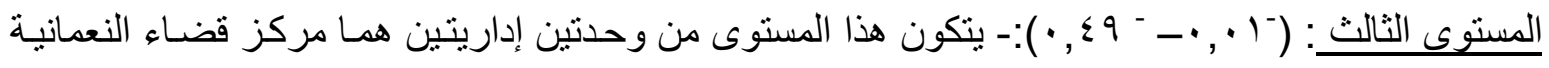
وناحية جصان بو اقع (r) متهمة لكل منهما . المستوى الر ابع: بدرجة(-• . • • فأقل ):- شمل هذا المستوى ناحيتي( الموفقية والدبوني) بـمتهمة واحدة لكل 
خريطة (r ا ) التوزيع الجغرافي لأعداد مرتكبات جريمة السرقة بحسب الوحات الإدارية في محافظة واسط لعام ـ 1. rم

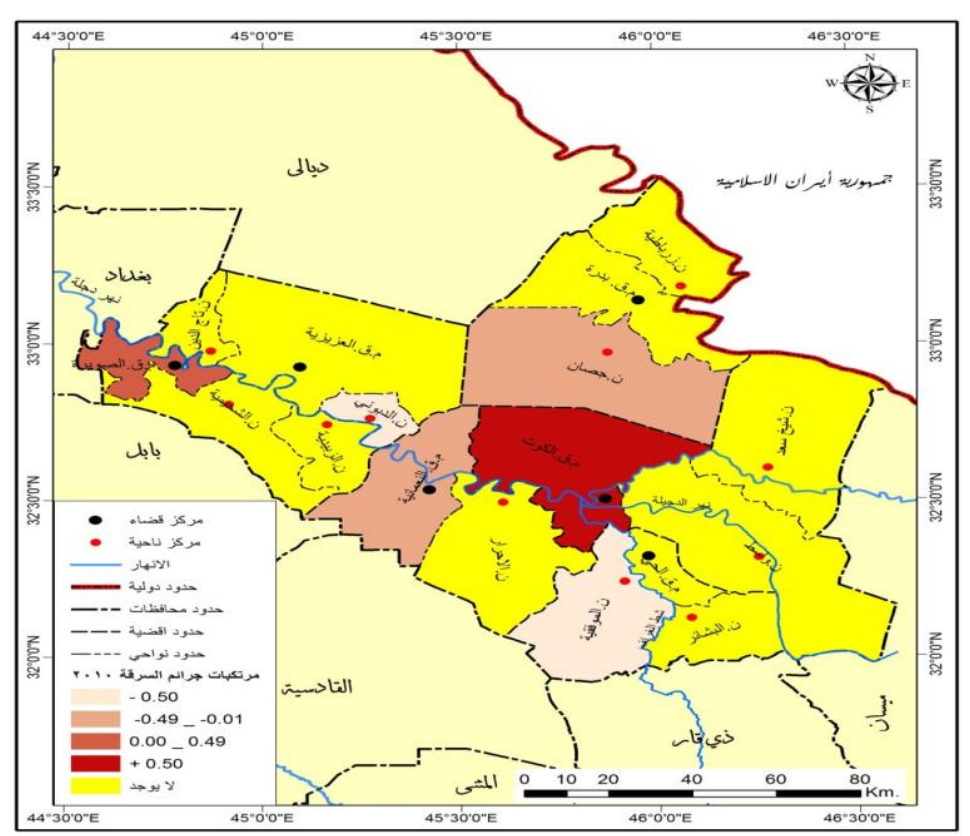

المصـــدر :- الباحــث

بالاعتماد على جدول(^) - (^)

أما بالنسبة للمتهمات بجريمة السرقة لعـام(ع ا ـ Y) تشير الخريطة(ع ا ) بوجود المستويات الأتية : المستوى الأول:( •0, ·- فأكثر): تمثل بمركز قضاء الكوت و الصويرة بـ(؟ و؟) متهمات على التوالي . المستوى الثانى:( 9 ـ, · - · , • ):- يضم هذا المستوى مركز قضاء النعمانية بواقع متهنتين بالسرقة .



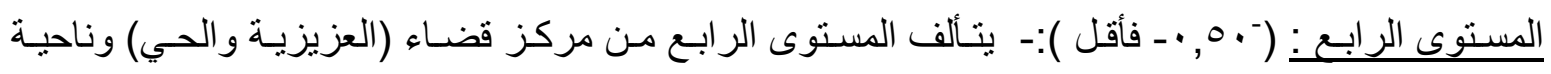
(الدبوني) وبنفس أعداد المتهمات البالغ متهة واحدة لكل منها . 
خريطة (ع () التوزيع الجغر افي لأعداد مرتكبات جريمة السرقة بحسب الوحدات الإدارية في محافظة واسط لعامء ( ب تم

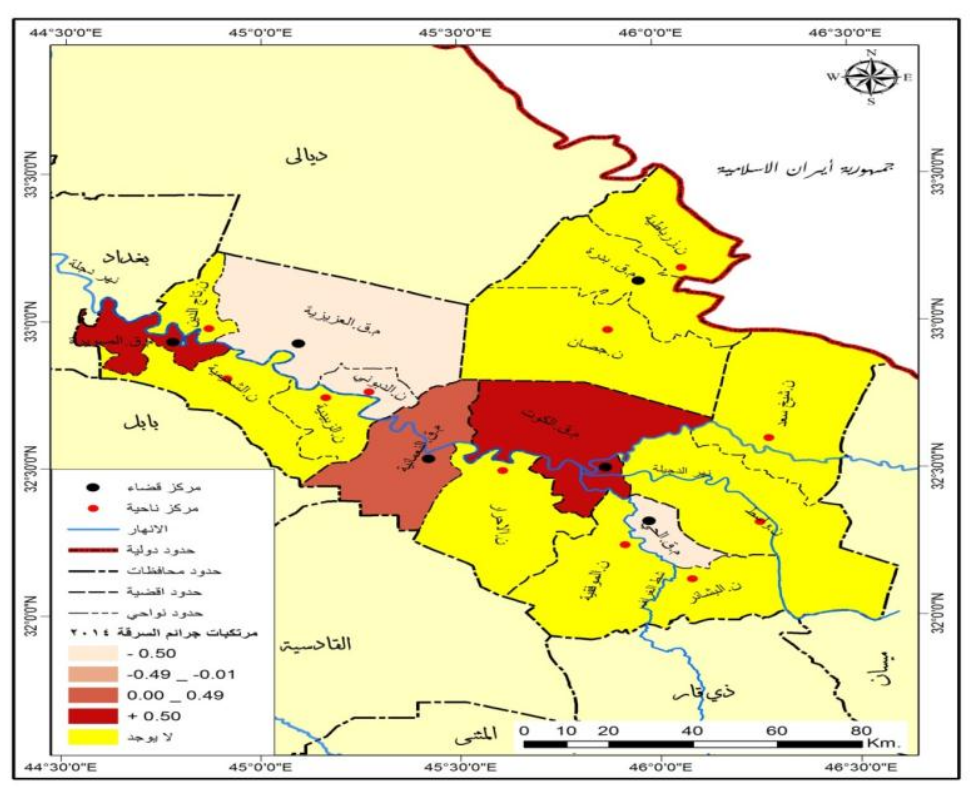

المصدر :- الباحث بالاعنماد على جدول(^) . (1) - (1)

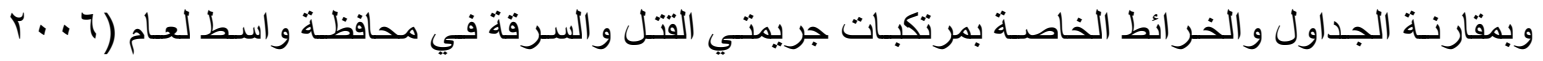
ولغاية ؟ ا ·rم) تتضح مجمو عة من المشاهدات الاتية :1 - انفر اد مركز قضـاء الكوت بـأعلى القيم لمرتكبـات جريمتي القتل و السـرقة ولجميع أعوام الدراسـة بو اقع

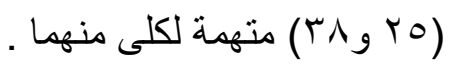
r - حاز مركز قضاء الصويرة على المرتبـة الثانية بالنسبة لمرتكبـات جريمتي القتل والسرقة، وبالإجمالي الكلي لمرتكبات جريمة القتل بـ( Y I ) متهمة، بينما بلغ أجمالي أعداد المتهمات بالسرقة بـ(7 ( ) متهمة .

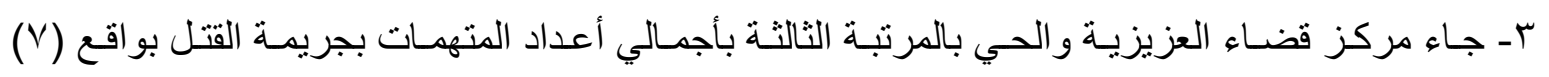
متهمات، بينما جاء مركز قضاء الحي بالمرتبة الثالثة بو اقع كلي للمتهمات بجريمة السرقة بـ(ع اء ) متهمة. rـ شهدت العديد من الوحدات الإدارية عدم تسجيلها لجريمتي القتل والسرقة ولعدة أعوام كما هو الحال

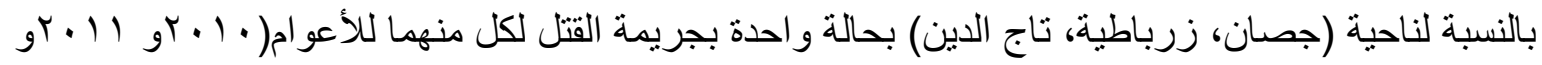
r Y • rم)، وكذلك الحال بالنسبة لمرتكبات جريمة السرقة فقد تم تسجيل حالة واحدة في نواحي(جصان،

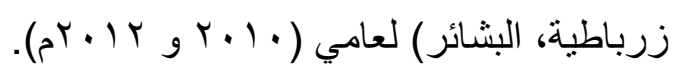
الاستتناجات:-

توصلت الدراسة من خلال اتباعها خطوات المنهج العلمي الجغر افي الى جملة من الاستنتاجات الاتية :1 - تميز الاتجاه العام لجريمتي القتل والسرقة في منطقة الدراسة بالانخفاض التدريجي في أعدادهِ بشكل عام

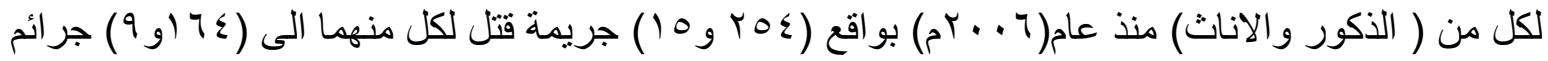




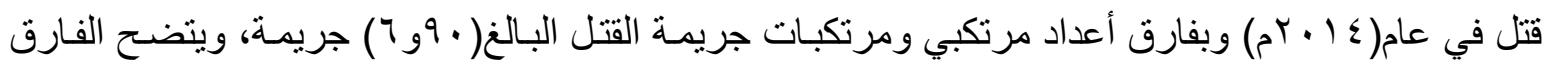

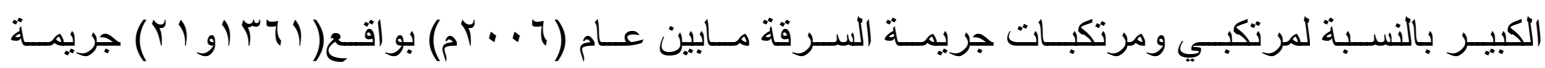

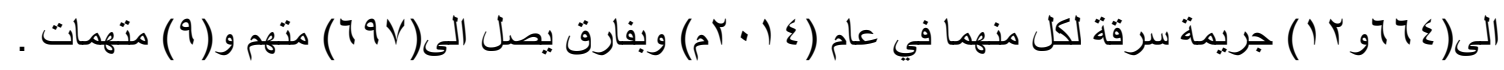
ז- أوضحت الدراسة حجم التباين المكاني الكبير في أعداد مرتكبي ومرتكبات جريمتي القتل و السرقة بين الوحدات الادارية في عموم منطقة الدراسة، حيث تثبر الدراسة الى استحواذ مركز قضساء الكوت على أعلى

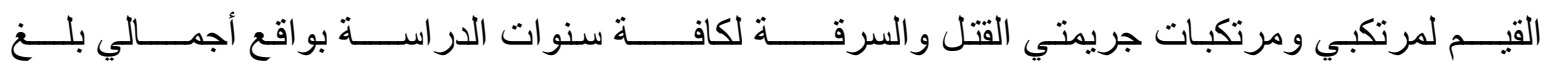

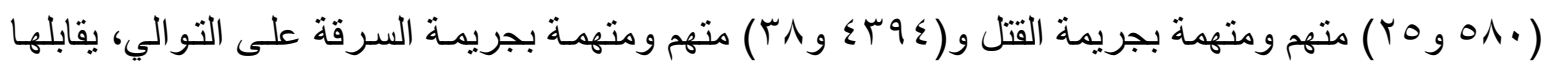
انخفاض واضح بأعداد مرتكبي ومرتكبات جريمتي القتل و السرقة في وحدات اداريـة اخرى كمـا هو الحسال بمركز قضاء بدرة ونواحي جصان وزرباطية مجتمعتاً، حيث بلغ اجمالي مرتكبي ومرتكبات جريمتي القتل



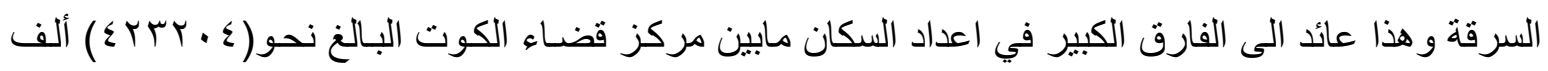


التنوع في حجم الوظائف وطبيعة العادات و التقاليد السائدة فيهما . هـ مـن النتائج المهــة التـي توصـلت أليهـا الدراسـة الميدانيـة هو تـأثر مجتمع منطقة الدراسـة بالعـادات

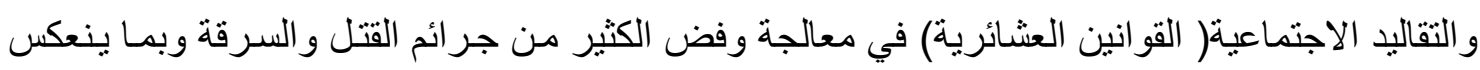
سلباً على دور الاجهزة الامنية في مكافحة الجريمة على اختلاف انواعها.

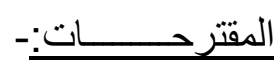
في ضوء الاستتناجات السابقة التي تم التوصل إليها سوف نتنـاول الدر اسـة أهم المقترحات التي يمكن من خلالها الحد والقضاء على ارتكاب جريمتي القتل و السرقة في محافظة واسط من وجهة نظر جغر افية ومن

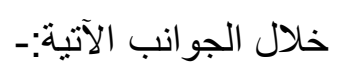

ا - لابد من الاسر اع بأنشاء قاعدة بيانات خاصة بمرتكبي ومرتكبات الجر ائم في محافظة واسط على اختلاف انو اعها وفق بر امج احصائية متكاملة معدة من قبل الجهات ذات الاختصاص لكونها تمثل قاعدت بيانات تستند عليها الدر اسة العلمية و البحثية بحيث تكون هذهِ البيانات منظمـة بطريقة علميـة ومبوبـة يَسـهل الحصول عليها و الابتعاد عن النمط القديم في عملية الحفظ الورقية من اجل الحفاظ عليها من التلف والسرقة . r- اقامـة بر امج التوعيـة والتوجيـه في المنـاطق الريفية على دور الاجهزة الامنيـة في مكافحة الجريمـة من خلال عقد الندوات والمؤتثر ات وبحضور رجـال الامن و الدين وشيوخ العشـائر ومنظمـات المجتمع المدني وتفعيل دور سلطة القانون في القضاء على الجريمة وفصلها عن العرف العثائري ونفوذهِ في حل مثل هذهِ الجر ائم نظر اً لما يتسبب بِهِ من عملية القتل والتسوية بنعرة قبلية يذهب ضحيتها العديد من الابرياء . 
r - محمد الأمين البشري، أنمـاط الجرائم في الوطن العربي، أكاديميـة نـايف العربية للعلوم الامنيـة، مركز الدراسـات و البحوث، الرياض،



r- كامل جاسم المر اياتي، رجاء محمد قاسم، الأحداث الجانحون و السرقة ( در اسـة في قسم تأهيل الأحداث في الكرخ ببغداد)، عدد خاص

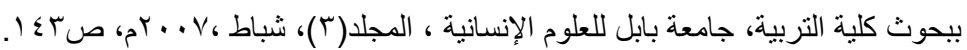

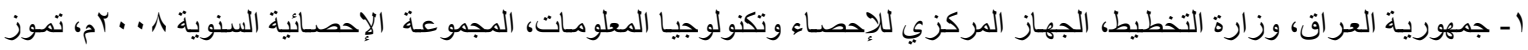

$$
\text { r. }
$$

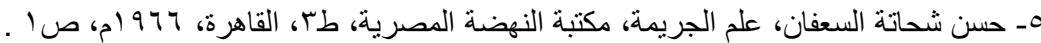

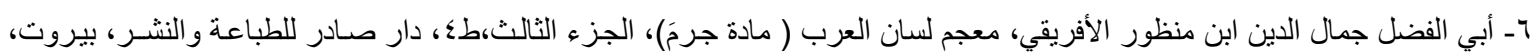

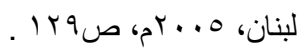

V - بدريـة عبد المنعم حسونة ، جريمـة القتل شبه العمد وأجزيتها المقررة في الثـريعة والقانون الجنائي السوداني، أكاديمية نـايف العربيـة



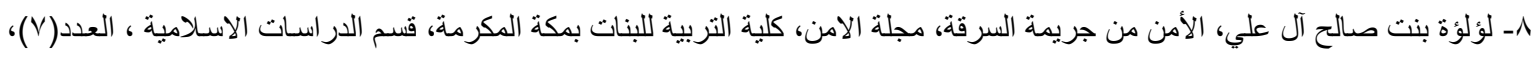

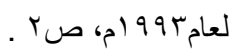

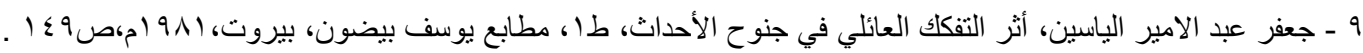

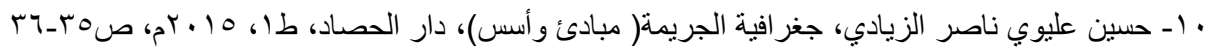

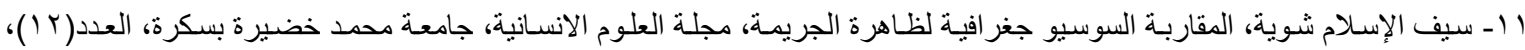

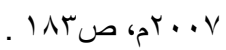
* - يقصد بـالتوزيع الجغر افي لأي ظـاهرة سكانية أعداد السكان المعنيين بالدر اسـة الذين يتو اجدون في منطقة محدودة وفي وقت معين

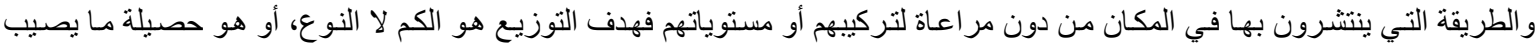
المنطقة أو الاقليم من حصة السكان أو نسبتهم سواء كان ذلك على مستوى الدولة أو على مستوى وحداتها الادارية . ينظر:- مصطفى عبداله محمد السويدي، تباين التوزيع الجغر افي لسكان في محافظة الفرات الاوسط، أطروحة دكتور اه ، قسم الجغر افيـة، كلية

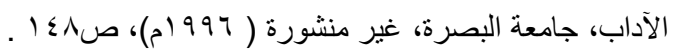
- حسين علي عبد محمد الراوي، تغير توزيع سكان الانبار وحركتهم المكانية، أطروحة دكتور اه ، الجغرافية، كلية الآداب، جامعة بغداد،

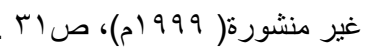
* - يرتبط مفهوم التوزيع العددي بعدد السكان أو بنوع الظاهرة المدروسة والذي ينت عدهم وحصر هم في منطقة معينة ووقت معبن، ويعتبر التوزيع العددي من الأساليب التي يمكن تمثيلها على الخريطة بتوفير البيانات الرقمية الخاصة بكل منطقة( وحدة إدارية) من حيث عدد السكان ونسبة ما يصيبها من إجمالي المنطقة، توضح هذه البيانات واختلافها زمانيا ومكانيا أهمية المكان.





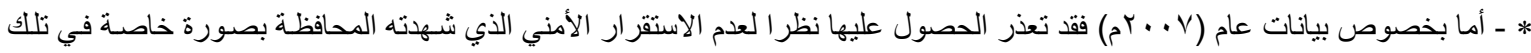
الفترة بسبب الأحداث التي جرت بين قوات الاحتلال الأمريكي وقوات الميليشيات مما أدى إلى عدم دقة ووضوح هذه البيانات وبصفة خاصـة جر ائم القتل و السرقة، لذا نم استثنائها .

rا - عبد الأمير عشوان، مظاهر السلوك الانحر افي للأحداث في مدينة النجف، رسالة ماجستير( غير منشورة )، مقدمة إلى الجامعة الحرة

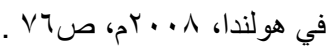

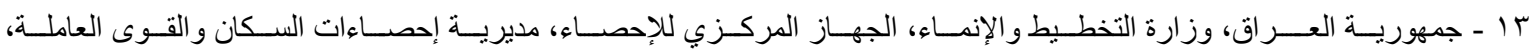

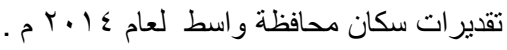




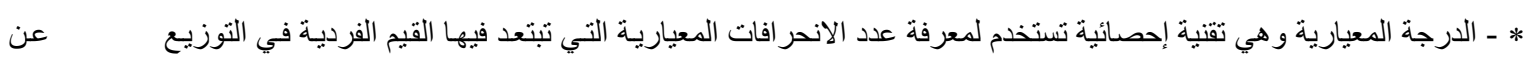
الوسط الحسابي، فهي من المقاييس المهمة لتحديد الموقع النسبي لكل قيمة في التوزيع لكونه يعطي القيمة الحقيقية لتوزيع أيـة ظـاهرة

$\frac{(\overline{-}-\omega)}{\varepsilon}=$ د:
إذ أن : د = الدرجة المعيارية / س أي قيمة من قيم المشاهدات س- = الوسط الحسابي/ ععالانحر اف المعياري . و لاستخر اج الانحر اف المعياري من خلال المعادلة التالية:



حيث أن : ع = الانحر اف المعياري / س = أي قيمة من قيم المشاهدات س- = الوسط الحسابي / = عدد المشاهدات. ينظر - عبد الرزاق محمد البطيحي، الاستخدام الأمثل لتقنيات التصنيف الكمي في الدراسـات الجغر افيـة ، مطابع وزارة التعليم العـالي و البحث



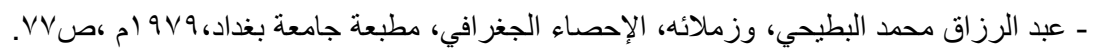

** ـ أما بالنسبة للتوزيع العددي فقد نم اختبار عدة فئات أو مستويات أخذين بنظر الاعتبار بأن هذا الاختيار لا يسمح ببقاء عدد من الفئات خالية من التكرار إلا في بعض الحالات . ـ ا ـ جمهوريـة العر اق، وزارة التخطبط، الجهاز المركزي للإحصـاء وتكنولوجيـا المعلومـات، مديريـة إحصـاءات السكان و القوى العاملـة ،

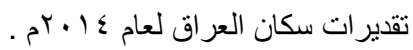
10 - جمهوريـة العر اق، وزارة التجارة، دائرة التخطيط والمتابعة ، فرع تموين واسط ، بيانات رسمية (غير منشورة)، جدول(ف) ، لعام 